\title{
The Ilopango caldera complex, El Salvador: Stratigraphic revision of the complete eruptive sequence and recurrence of large explosive eruptions
}

\author{
Ivan Suñe-Puchol ${ }^{\mathrm{a}, *}$, Gerardo J. Aguirre-Díaz ${ }^{\mathrm{a}}$, Dario Pedrazzi ${ }^{\mathrm{b}}$, Pablo Dávila-Harris ${ }^{\mathrm{c}}$, Daniel P. Miggins ${ }^{\mathrm{d}}$,

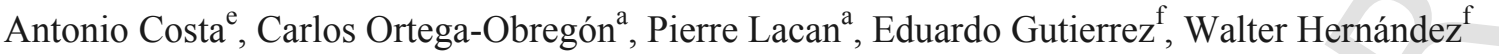 \\ ${ }^{a}$ Centro de Geociencias, Universidad Nacional Autónoma de México, Blvd. Juriquilla 3001, Campus UNAM-Juriquilla, Querétaro, 76230, Mexico \\ ${ }^{\mathrm{b}}$ ICTJA, CSIC, Group of Volcanology, SIMGEO UB-CSIC, Institute of Earth Sciences Jaume Almera, Lluis Sole i Sabaris s/n, 08028 Barcelona, Spain \\ ' División de Geociencias Aplicadas, IPICYT, 78216 San Luis Potosí, Mexico

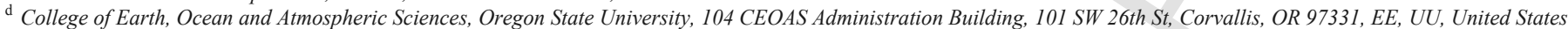 \\ of America \\ ' Instituto Nazionale di Geofisica e Vulcanologia, INGV-Bologna, Via Donato Creti, 12, 40100 Bologna, Italy \\ ${ }^{\mathrm{f}}$ Gerencia de Geología del Observatorio Ambiental, Ministerio de Medio Ambiente y Recursos Naturales MARN, San Salvador, 76230, El Salvador
}

\section{A R T I C L E I N F O}

\section{Article history:}

Received 13 November 2018

Received in revised form 11 February 2019

Accepted 16 February 2019

Available online $\mathrm{xxx}$

Keywords:

Stratigraphy of pyroclastic deposits

Tectonic-caldera

Ignimbrite

Central America Volcanic Arc

Pull-apart graben

\begin{abstract}
A B S T R A C T
Ilopango caldera erupted episodically at least 13 tuff-forming eruptions with a minimum estimate volume of $1-5 \mathrm{~km}^{3}$ DRE per eruption, reaching up to $150 \mathrm{~km}^{3}$ DRE for the first caldera-forming eruption. All tuffs are of dacitic-rhyolitic composition. The complete pyroclastic sequence spans a range in time from 1.785 to $0.0015 \mathrm{Ma}$, and based on stratigraphy and geochronology constraints can be divided into three formations: the Comalapa, Altavista and Tierras Blancas formations. In this work, we focus on the members of the newly described Altavista Formation (middle part of Ilopango caldera volcanic sequence), which consist of six consolidated pyroclastic deposits or tuffs. Each tuff corresponds to a specific eruption followed by a period of quiescence during which soil beds were developed on the deposits. The ages of the Altavista Formation ranges from 918 to $257 \mathrm{ka}$, based on new ${ }^{40} \mathrm{Ar} /{ }^{39} \mathrm{Ar}$, U/Pb-zircon, and U/Th-zircon analyses. The tuffs of this formation show similar characteristics in mineralogy and composition. They are calcalkaline, rhyodacitic tuffs, with plagioclase, clinopyroxene, and hornblende. From field mapping and descriptions of the deposits, we have inferred the eruptive styles that include pumice fallouts, pyroclastic density currents and also hydromagmatic explosions. The common vent in all tuffs was the Ilopango caldera and each member of the Altavista Formation could correspond to a caldera collapse event, except for one of the six eruptions. The volume of each member was estimated to be $>30 \mathrm{~km}^{3}$ DRE, which is the same order of magnitude than that estimated for the Tierra Blanca Joven (TBJ) eruption at about 1500 B. P, and smaller than those of the ignimbrites of the Comalapa Formation, the first three members of the Ilopango caldera reported previously. The tuffs of the Altavista Formation are visible up to $15-20 \mathrm{~km}$ away from the caldera's topographic margin. The recurrence interval of large explosive events at the Ilopango caldera was established by integrating the stratigraphic and geochronologic data of all 13 ignimbrites and pumice fallouts erupted from Ilopango caldera since the first one at $1.78 \mathrm{Ma}$ to the last explosive event (TBJ).
\end{abstract}

(C) 2019

\section{Introduction}

Ilopango Caldera (IC), located at El Salvador Volcanic Front (Fig. 1 ), is one of the largest active volcanoes of the Central America Volcanic Arc (CAVA). IC is $17 \mathrm{~km} \times 13 \mathrm{~km}$ in size and it is filled by an intra-caldera lake (Fig. 1). Caldera's history includes several collapses associated to large explosive ignimbrite-forming eruptions; the initial volcanic phases of this caldera includes the Olocuilta, Colima, and Apopa ignimbrites at 1.78-1.34 Ma (Suñe-Puchol et al., 2019). These early eruptions of the IC sequence were linked with the regional tectonics of El Salvador Fault Zone at that time (Suñe-Puchol et al., 2019), confirming the interpretation by previous authors that IC is a

\footnotetext{
* Corresponding author.

Email address: ivanbatea@gmail.com (I. Suñe-Puchol)
}

volcano-tectonic depression (Williams and Meyer-Abich, 1955; Golombek and Carr, 1978; Hutton and Reavy, 1992; Sofield, 2004; Saxby et al., 2016; Aguirre-Díaz and Martí, 2015; Aguirre-Díaz et al., 2016, 2017). The early ignimbrites of the IC were voluminous, for example, the Olocuilta ignimbrite, with a minimum Dense Rock Equivalent (DRE) volume of $60 \mathrm{~km}^{3}$ that could reach at least $150 \mathrm{~km}^{3}$ involving inferred covered or eroded deposits (Suñe-Puchol et al., 2019), representing so far the largest recorded from the IC.

The most recent explosive episodes occurred during the last $57 \mathrm{ka}$ and corresponded to the Tierras Blancas tuffs (or TB's), defined as TB4, TB3, TB2 and TBJ (CEL, 1992; Rose et al., 1999; Hernández, 2004; Kutterolf et al., 2008; Lexa et al., 2011; Pedrazzi et al., 2018). The youngest Tierra Blanca Joven (TBJ) occurred only $\sim 1500 \mathrm{yr}$ ago (Dull et al., 2010) and affected significantly the Mayan population of the central part of El Salvador with $\sim 80 \mathrm{~km}^{3}$ of erupted magma (Sheets, 1979; Dull et al., 2001, 2010; Pedrazzi et al., 2018). 


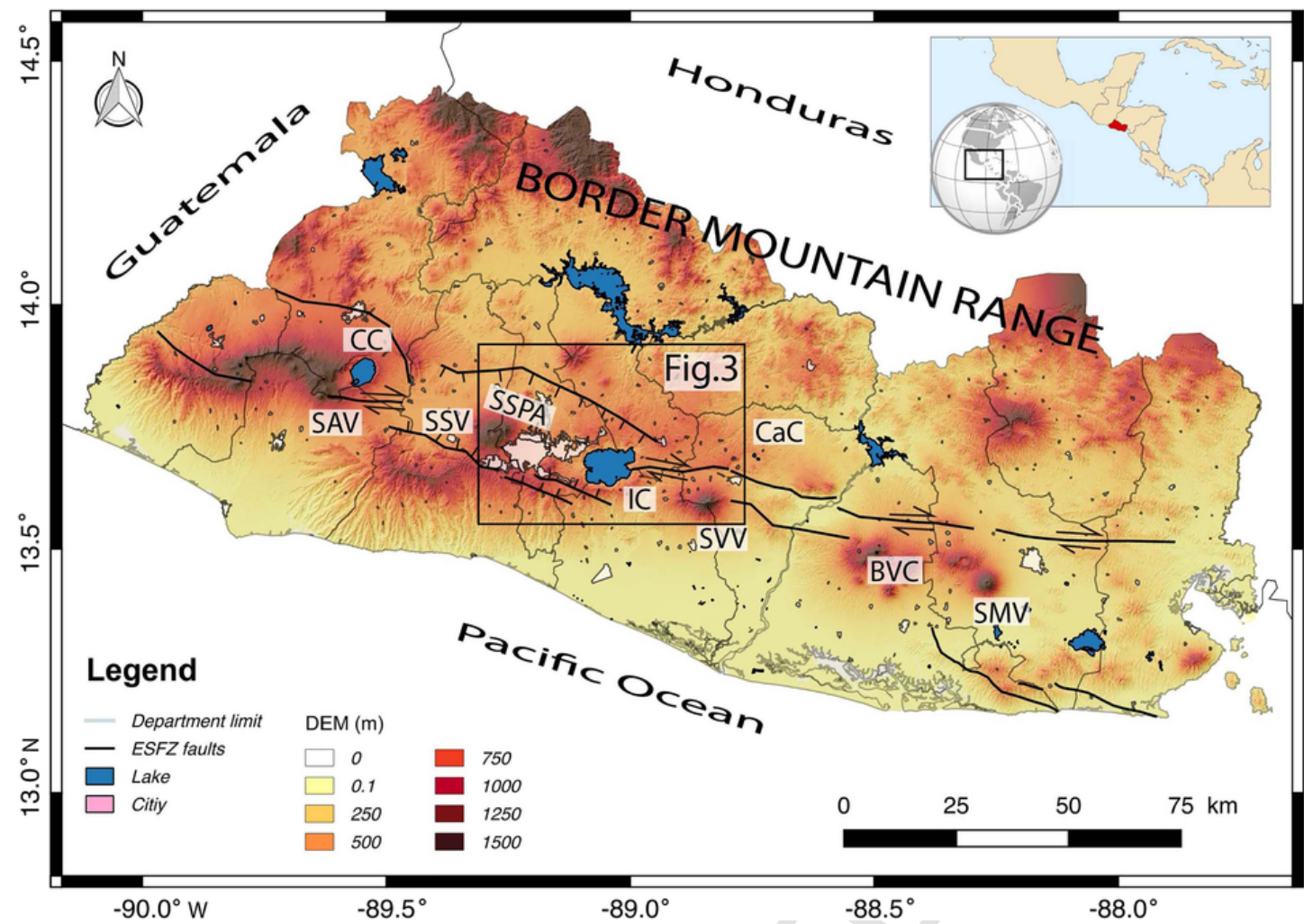

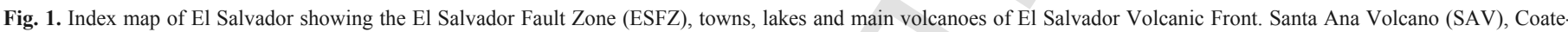

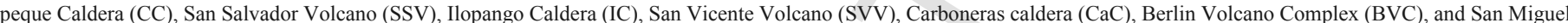

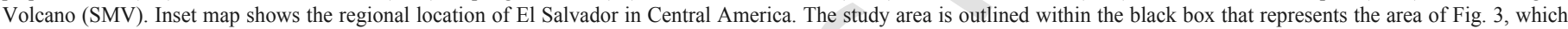
includes the San Salvador Pull-Apart (SSPA).

The aim of this work was to identify and characterize the tuff-forming eruptions occurred between the early ignimbrites of IC (Suñe-Puchol et al., 2019), and the last Tierras Blancas tuffs (Rose et al., 1999; Kutterolf et al., 2008), that is, the eruptions occurred between $1.34 \mathrm{Ma}$ to $57 \mathrm{ka}$. In addition, we provide a formal volcano-stratigraphic nomenclature to the Ilopango Group according to Martí et al. (2018). A recurrence timing of all the major explosive eruptions from IC was established by integrating the data of, 1) the Comalapa Formation (the three early ignimbrites of IC, Suñe-Puchol et al., 2019); 2) the Altavista Formation (the six tuffs presented in this work), and; 3 ) the Tierras Blancas Formation from published data (Weber and Wiesemann, 1974; Rose et al., 1999; Kutterolf et al., 2008).

\section{Geologic and volcano-stratigraphic context of Ilopango caldera}

The geology of El Salvador consists of a Jurassic - Cretaceous limestone basement mostly covered by Eocene to Holocene volcanic rocks (Appendix A; Weber and Wiesemann, 1974). Oligocene volcanism was located along the northernmost part of the country and formed the Border Mountain Range, a natural boundary between El Salvador and Honduras that includes Morazán and Chalatenango Formations (Fig. 1; Donnelly et al., 1990). Since the Miocene, volcanic activity migrated southward approaching to the Mesoamerican trench, where the active volcanoes are located forming the El Salvador Volcanic Front (Reynolds, 1987; Alonso-Henar et al., 2017; Fig. 1).

The actual magmatism of El Salvador Volcanic Front is related to the subduction of Cocos plate underneath the Caribbean plate at an average speed of 73-85 mm/year (Dixon, 1993; Mann, 2007; DeMets,
2001). The high movement rates of these plates are also responsible for the elevated regional seismic activity along the El Salvador Fault Zone (ESFZ, Martínez-Díaz et al., 2004), which is a narrow zone of en-echelon right-stepping dextral faults connected by transtensional pull-apart basins that crosses the country WNW-ESE (DeMets, 2001, Agostini et al., 2006; Funk et al., 2009; Canora et al., 2012; Fig. 1). IC is located along the ESZF, specifically within one of its tectonic basins: the San Salvador Pull-Apart (Fig. 1; Garibaldi et al., 2016). The active faults of the San Salvador Pull-Apart are controlling volcanism and are likely used as the preferential pathways for magma rising to the surface (Hutton and Reavy, 1992; Sofield, 2004; Saxby et al., 2016; Suñe-Puchol et al., 2019).

\subsection{Volcanic stratigraphy of Ilopango caldera (IC) products}

In previous studies on the IC and surroundings areas, Weber and Wiesemann (1974) grouped the older deposits of this caldera within the Cuscatlán Formation together with lahars and deposits from other volcanoes. The IC tuffs studied in this work (time span of 917-257 ka) and the early ignimbrites of the same caldera $(1.78-1.34 \mathrm{Ma}$, Suñe-Puchol et al., 2019), belongs to this formation. The upper limit of this Cuscatlán Formation is marked by the 57 ka Congo tephra deposit (Rose et al., 1999), a Plinian fall from the Coatepeque caldera (Fig. 1). The last four tuffs of IC (TB's) are included into the San Salvador Formation (Weber and Wiesemann, 1974), together with the Upper Pliocene -Holocene eruptions from other young Salvadorian volcanoes (f. ex. from Coatepeque caldera, San Salvador volcano, Santa Ana volcano, San Miguel volcano).

In this study, a new classification for the IC products was established with the aim of a standardization, which accounts for modern 
volcano-stratigraphy criteria (Fig. 2). Following the formal nomenclature established by Martí et al. (2018), we grouped the IC deposits in the Ilopango Group (new name) to distinguish it from previous lithological groups not directly related to the activity of Ilopango. This Ilopango Group is subdivided into three new formations based on stratigraphy and geochronology constraints, as eruption magnitudes, quiescence periods, unconformities, volcanic processes and tectonic settings. These new formations are, 1) Comalapa Formation, which comprise the first three ignimbrites of IC (Suñe-Puchol et al., 2019); 2) Altavista Formation that includes the six tuffs studied in this work; and 3) Tierras Blancas Formation, encompassing the last four tuffs erupted by IC (Rose et al., 1999; Kutterolf et al., 2008). Fig. 2 illustrates the equivalence between the older formations classification of Weber and Wiesemann (1974) and the new classification described in this study, establishing a comparison by isochrones. As with the Comalapa Formation of IC (Suñe-Puchol et al., 2019), we define and describe here the ignimbrites and fallout deposits of the Altavista Formation.

\section{Methodology}

A preliminary remote sensing analysis of the area was done based on satellite images and a Digital Elevation Model (DEM) of $10 \mathrm{~m}$ resolution. Geological fieldwork was initially based on El Salvador geological map of 1: 500,000 (Weber and Wiesemann, 1974), and also on previous maps and stratigraphy reported by other authors (Hernández, 2008; Garibaldi et al., 2016). Four fieldwork campaigns around IC between 2015 and 2017 of about 2 weeks of duration and at least 2 geologists working per campaign, allowed us to elaborate a

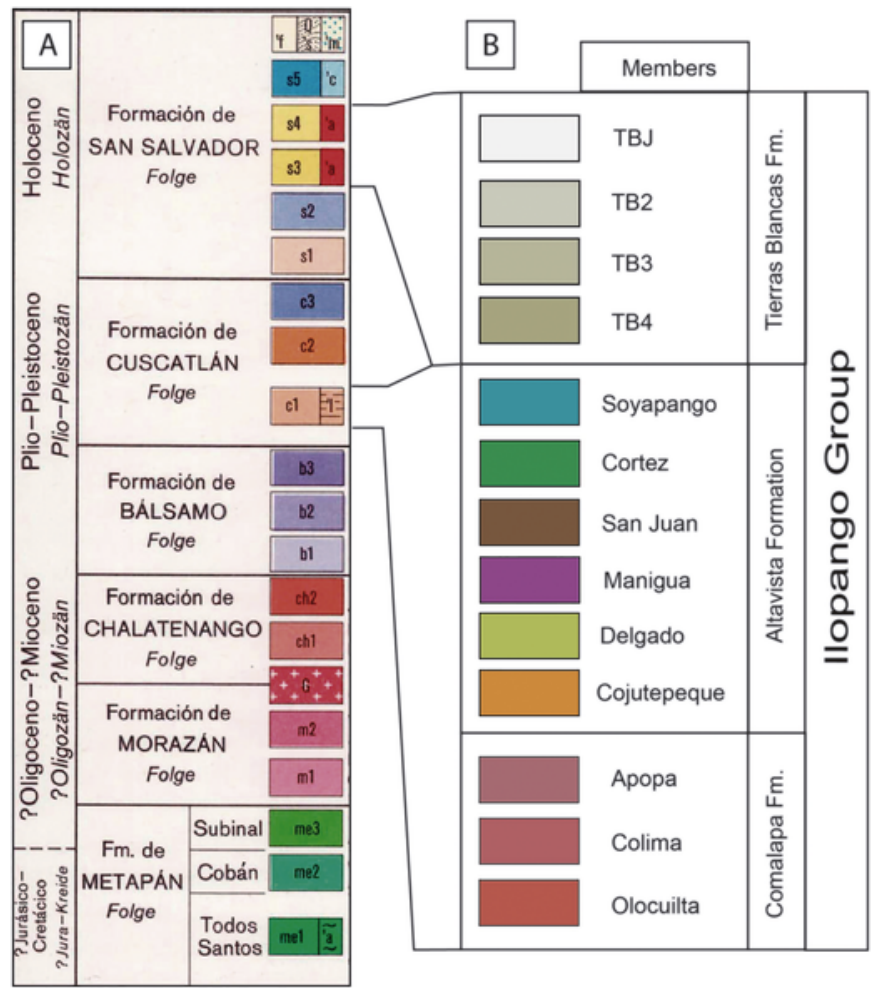

Fig. 2. Equivalence between older and the new volcano-stratigraphic classification of the Ilopango Group proposed in this study. a) Formations of El Salvador (Weber and Wiesemann, 1974). b) The new volcano-stratigraphic nomenclature that includes the Comalapa, Altavista and Tierras Blancas formations of the Ilopango Group (following the nomenclature proposed by Martí et al., 2018). new geologic map focused on the distribution of the Altavista Formation tuffs. This map covers about $2000 \mathrm{~km}^{2}$ of the central part of El Salvador Country, from Guazapa Volcano at the north, to the Balsamo mountain range at the south; and from the San Salvador volcano at the west, and Carbonera caldera to the east (Fig. 3).

Each tuff within the Altavista Formation was sampled for laboratory analysis. Major, trace and Rare Earth-Elements (REE) were measured as whole-rock for chemical analyses. Trace and REE were carried out by means of a Thermo ICAP-Q quadruple mass spectrometer (ICP-MS), at the Laboratory of Isotopic studies (LEI), Center for Geosciences (CGEO) of the National Autonomous University of Mexico (UNAM). Analysis of major and trace elements were carried out at Institute of Geology, UNAM, with an X RIGAKU ZSX Primus II spectrometer, following standard sample preparation and analytical techniques of Bernal and Lozano-Santacruz (2005).

$\mathrm{U} / \mathrm{Pb}, \mathrm{U} / \mathrm{Th}$ and ${ }^{40} \mathrm{Ar} /{ }^{39} \mathrm{Ar}$ geochronological analyses on each member of Altavista Formation were performed in order to support the stratigraphic correlation and constrain accuracy the IC explosive eruption ages. For deposits younger than $350 \mathrm{ka}$ we used U/Th technique instead of $\mathrm{U} / \mathrm{Pb}$ in zircons, because of the lack of secular equilibrium (Bernal et al., 2014). Zircon samples were separated and dated at the Laboratory of Isotopic Studies-LEI of CGEO-UNAM, using a $193 \mathrm{~nm}$ Resolution M50 laser ablation inductively coupled to a plasma mass spectrometer (LA-ICP-MS) Thermo ICAP Qc for U/Pb following the method described in Ortega-Obregón et al. (2013) and to a Thermo Neptune plus for $\mathrm{U}-\mathrm{Th}$ ages following methodology described by Bernal et al. (2014). To obtain juvenile zircon crystals, pumice fragments were isolated, removing altered surfaces and then crushed and sieved to fractions of $74-44 \mu \mathrm{m}$. This fraction was then washed using a plastic pan to concentrate the heavy crystals from the lighter glass. Mineral concentrates were magnetically separated by means of a Frantz Isodynamic Separator to further concentrate the zircons. Representative zircons were handpicked under a binocular microscope and checked for purity and zoning using an ELM-3R luminoscope by cathodoluminescence (Marshall, 1988), before and after the ICP-MS laser ablation analysis. About 50 zircon grains per sample were selected in order to obtain a statistically representative age.

Samples for ${ }^{40} \mathrm{Ar} /{ }^{39} \mathrm{Ar}$ dating were prepared, irradiated and analyzed at the Argon Geochronology Laboratory of the Oregon State University (OSU), using an Argus-VI multi-collector mass spectrometer. As with zircons, clean pumice clasts were separated and crushed to obtain mineral concentrations. Crushed samples were sieved to $500-177 \mu \mathrm{m}$ fractions and washed with deionized water using an ultrasonic bath to remove dust. Feldspars were magnetically separated from amphiboles and pyroxenes, and all phases were acid-leached following the methods of Koppers et al. (2011). The only available phases to date the members of the Altavista Formation were plagioclase and hornblende (ultra-pure separates picked clean of melt inclusion-rich crystals). Incremental heating was performed on bulk samples for each mineral phase. Mineral concentrations were used since individual grains did not yield enough radiogenic argon for accurate single-crystal total fusion analyses. To achieve the highest possible precision in the ${ }^{40} \mathrm{Ar} /{ }^{39} \mathrm{Ar}$ age determinations, a large number of heating steps (22-33 heating steps) were carried out for each sample. Plateau age chosen included as many contiguous and concordant step ages as possible to obtain an acceptable mean square weighted deviates (MSWD). System blanks were measured throughout the analysis. To get the appropriate eruption age it was necessary to recalculate them using the Kuiper et al. (2008) age by the Fish Canyon Tuff as flux monitor, reducing the data with the ArArCALC v2.5.1 software from Koppers (2002). All the ${ }^{40} \mathrm{Ar} /{ }^{39} \mathrm{Ar}$ age errors reported here are 


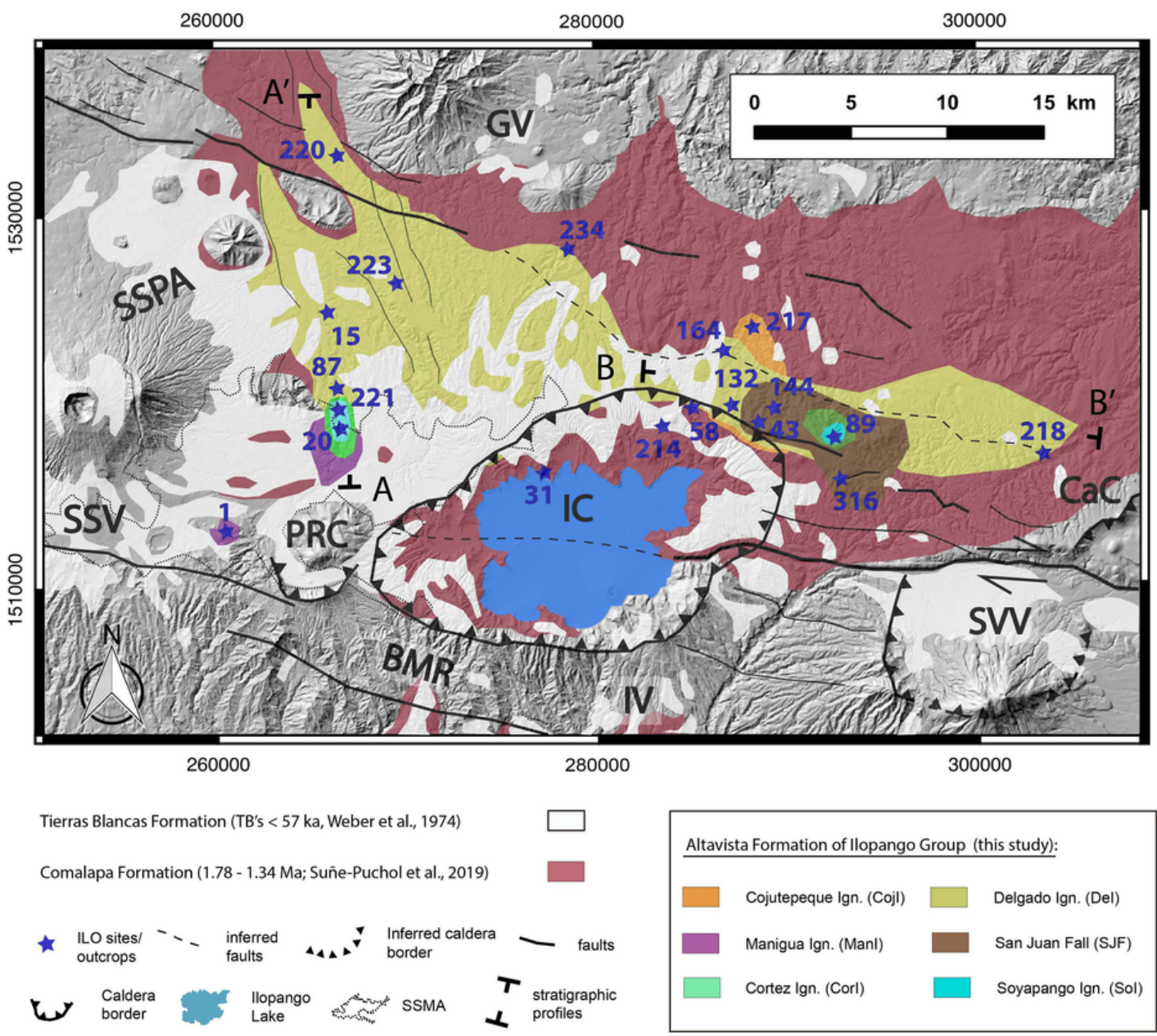

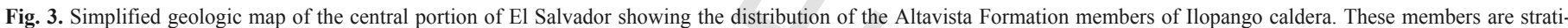

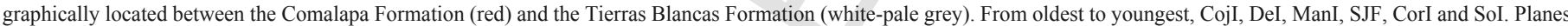

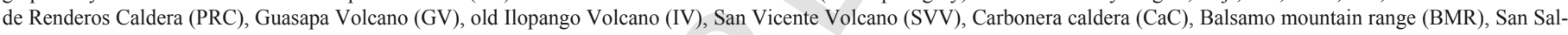

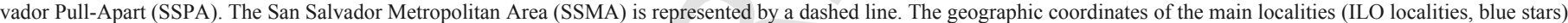
are in UTM using Datum: D_WGS_1984, zone 16P. (For interpretation of the references to colour in this figure legend, the reader is referred to the web version of this article.)

$2 \sigma$. More details of the techniques employed in the dating process are provided in Appendix B.

\section{Results}

\subsection{The Altavista Formation tuffs of Ilopango Caldera: description and distribution}

Six pyroclastic deposits separated by paleosols were identified in the field for the Altavista Formation. They overly the older ignimbrites of IC (Comalapa Formation) and are covered by the Tierras Blancas Formation. From oldest to youngest, these six members that conform the Altavista Formation are: the Cojutepeque Ignimbrite (CojI), Delgado Ignimbrite (DeI), Manigua Ignimbrite (ManI), San Juan pumice Fall (SJF), Cortez Ignimbrite (CorI) and Soyapango Ignimbrite (SoI). They are poorly-consolidated and unwelded deposits, and thus, are soft and easily eroded away. Their poor preservation results in the lack of lateral continuity of the Altavista Formation tuffs and scarce sites with preserved total thicknesses (Fig. 3). However, useful exposures were identified along the Panamerican Highway that crosses the San Salvador Pull-Apart along the northern sector of IC
(Figs. 5, 6 and 7). In addition, several quarries and other good outcrops allowed us elaborating a composite stratigraphic section of the Altavista Formation tuffs (Fig. 4) by stratigraphic correlation (profiles A and B of Fig. 8) and supported by petrochemical and geochronological analyses (Figs. 9, 10, 11 and 12).

The index map (Fig. 3) shows the morphology of the study area and the spatial distribution of the six tuffs of Altavista Formation. Broadly, these members have not a generalized or radial distribution around the IC as in the older ignimbrites of the Comalapa Formation (Suñe-Puchol et al., 2019), or as the youngest TBJ (from the Tierras Blancas Formation; Fig. 3). Some deposits of the Altavista Formation have a very local distribution, such as ManI or CorI. Other deposits have an average distribution area of $\sim 100 \mathrm{~km}^{2}$, such as SJF or CojI. The DeI is the most widespread tuff and with the best exposures as far as $10-15 \mathrm{~km}$ from the caldera border (ILO-220, -234, and -218; Fig. 3 ). The tuffs of Altavista Formation were not found on the southern flank of IC mainly because of erosion.

\subsubsection{Cojutepeque Ignimbrite (CojI)}

CojI is not distributed radially around IC and it only crops out along the northeast border of the caldera (Fig. 3). At ILO-43 (Figs. 3 


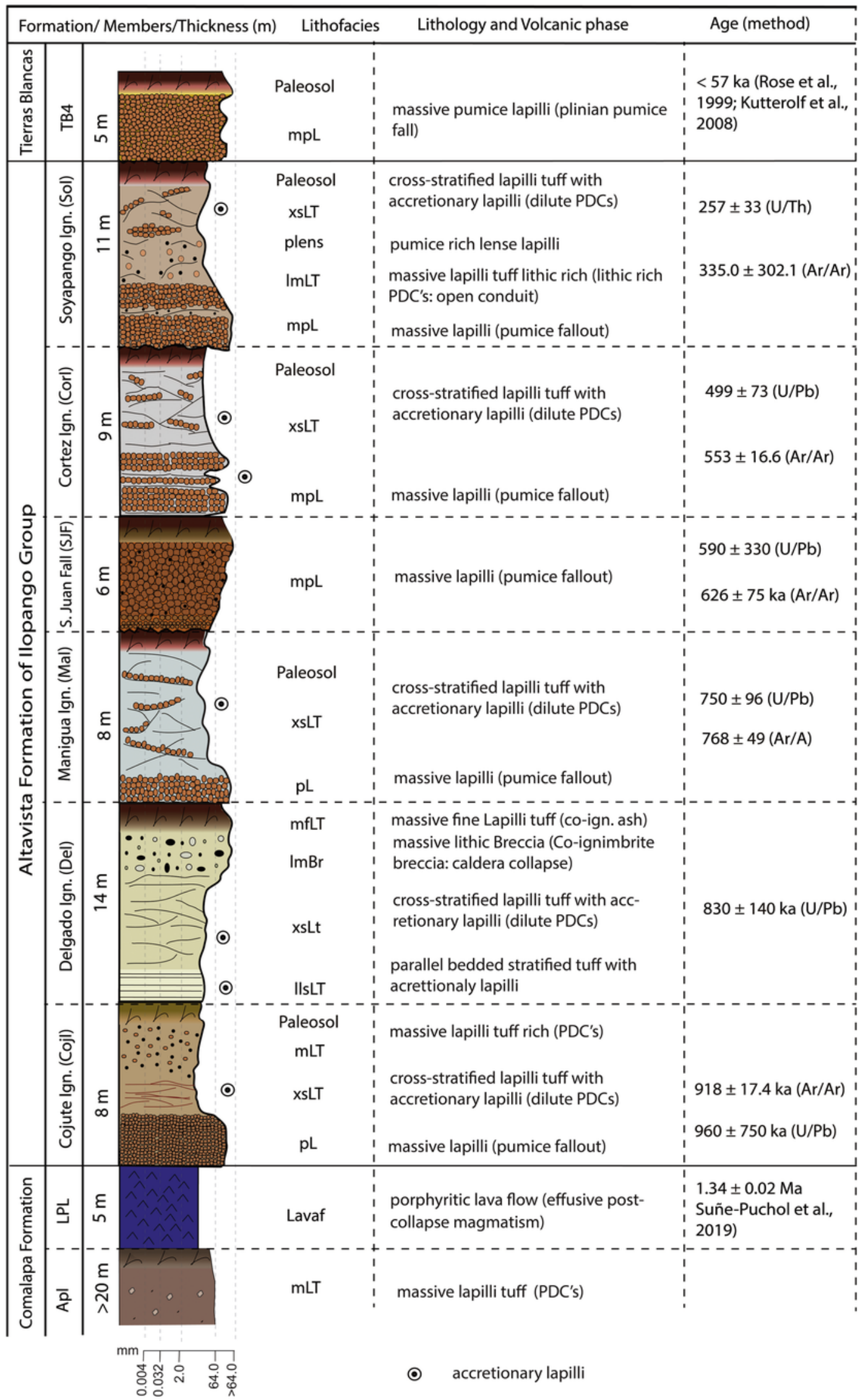


and 5) this oldest tuff of Altavista Formation overlays a thick paleosol of $\sim 1 \mathrm{~m}$ thick developed at the top of the $1.32 \pm 0.02 \mathrm{Ma}$ Las Pavas Lava (LPL, Suñe-Puchol et al., 2019), which corresponds to a post-collapse dome that represents the youngest unit of the Comalapa Formation of IC. The base of CojI consists of an orange-brown well-classified pumice layer, which reaches a thickness of $2 \mathrm{~m}$ at ILO-132 and ILO-144 (mpL; Figs. 3 and 5f). Pumices are $1-3 \mathrm{~cm}$ in diameter with plagioclase, hornblende, and clinopyroxene (Table 1), and smaller amounts of $\mathrm{Fe}-\mathrm{Ti}$ oxides and zircon (Fig. 9a and b). Above the basal pumice layer, there are $\sim 1 \mathrm{~m}$ of cross-stratified layers (xsLT; Fig. 5c), composed of fine ash and abundant accretionary lapilli, with thin oxidized zones that remark the lamination of the layers. The top of this tuff is made of 4-5 $\mathrm{m}$ of a massive pyroclastic deposit supported by ash, with pumice lenses and lithics of dacitic lava $(1-2 \mathrm{~cm})$.

\subsubsection{Delgado Ignimbrite (DeI)}

DeI corresponds to the second member of the Altavista Formation, and it is the most widespread ignimbrite of this formation (Fig. 3 ). It is found about $20 \mathrm{~km} \mathrm{NW}$ of the caldera border, next to the western flank of Guasapa Volcano and outside of the San Salvador Pull-Apart (ILO-220, Fig. 3). DeI shows a parallel-stratified base layer that ranges in thickness from a few $\mathrm{cm}$ to $\sim 1 \mathrm{~m}$, and consists, in the lower part, of an accretionary lapilli-rich fine ash bearing pumice deposit with lithic fragments smaller that $1 \mathrm{~cm}$ (1lsLT; Fig. 6e). The middle part of this deposit consists of 5-6m of cross-stratified ash-rich tuff (xsLT; Fig. 6f), with small pumice fragments and accretionary lapilli, but poorer in lithics than the basal zone. At the top, this member changes to a semi-consolidated massive lapilli tuff, about $5 \mathrm{~m}$ thick, with the presence, in some sites, of a lithic breccia level with diffuse parallel stratification (dsILT; Fig. 5e; ILO-43). Mineralogy includes plagioclase, hornblende, clinopyroxene and rare primary quartz (Table 1).

\subsubsection{Manigua Ignimbrite (ManI)}

This ignimbrite is only exposed on the western sector of IC (Fig. 3 ), mostly along the roadcuts of the Panamerican Highway, such as ILO-20 (Figs. 3 and 7), called as Staircase site by Garibaldi et al. (2016). At this locality, 7-8 km far away from the WNW topographic margin of the caldera, each member of Altavista Formation is affected by normal faults of the San Salvador Pull-Apart system (Fig. 3). The base of ManI consists of a layer of $0.3 \mathrm{~m}$ thick, well-classified, clast-supported pumice layer $(\mathrm{mpL})$. The fresh pumice is white-brown, but it shows a dark patina due to oxidation (Fig. 7f). This pumice is crystal-poor, with plagioclase, hornblende and quartz, with accessory minerals of Fe-Ti oxides, zircons and few clinopyroxene phenocrysts (Table 1). Directly above of this basal pumice fall layer, there is a $8-9 \mathrm{~m}$ of fine-ash and accretionary lapilli rich cross-stratified tuff (xsLT, Fig. $7 \mathrm{f}$ and g), with few, intercalated, thin, levels rich in pumice fragments-rich levels ( $\mathrm{pLens}$ ).

\subsubsection{San Juan Pumice Fall (SJF)}

The SJF is a well-classified, clast-supported pumice deposit ( $\mathrm{mpL})$, moderately rich in lava lithics $(\sim 10-15 \mathrm{vol} \%)$. This member reaches 4-5 $\mathrm{m}$ thick in ILO-316, $5 \mathrm{~km}$ away from the NE margin of the caldera (Fig. 3). The pumices are $1-3 \mathrm{~cm}$ in diameter and contain abundant plagioclase, clinopyroxene and hornblende phenocrysts (Table 1 and Figs. 9c, d, g and h), with smaller amounts of $\mathrm{Fe}-\mathrm{Ti}$ oxides and zircons. The first $10 \mathrm{~cm}$ of the SJF show inverse grading, from coarse-ash to pumice lapilli. This pumice deposit overlays the paleosol formed at the top of the DeI (f. ex. in ILO-43; Fig. 5b). At ILO-89 (NE sector of the IC; Fig. 3), SJF is deposited above an angular unconformity (Figs. 6b and c). This member is not present in the NW sector of the caldera.

\subsubsection{Cortez Ignimbrite (CorI)}

The CorI covers the SJF at ILO-89 (Fig. 3) with a series of fine ash-rich cross-stratified tuff with accretionary lapilli (xsLT, Fig. 6). However, in the NW sector of the caldera (e.g. at ILO-20; Fig. 3), where CorI is deposited above the paleosol on ManI's top, its base consists of $\sim 1 \mathrm{~m}$ of well-classified clast-supported pumice fall deposit (mpL), with two thin levels of fine-ash rich deposits intercalated $(<10 \mathrm{~cm}$ thick, Fig. 7e). The CorI pumice clasts are very poor in crystals with sparse plagioclases, biotite and quartz phenocrysts, and $\mathrm{Fe}-$ Ti oxides and zircons (Table 1). Above this pumice deposit, there is a sequence of cross-stratified fine-ash and accretionary lapilli-rich tuff (xsLT) that is very poor in lithics.

\subsubsection{Soyapango Ignimbrite (SoI)}

The base of SoI consists of $\sim 2 \mathrm{~m}$ of well-classified, clast-supported pumice layer $(\mathrm{mpL})$, deposited over an eroded surface at the top of CorI (Figs. 6 and 7). Pumice clasts of this member are crystal-poor, with few plagioclase and minor amounts of $\mathrm{Fe}-\mathrm{Ti}$ oxides and zircon (Table 1). Above the basal pumice layer there are $3-4 \mathrm{~m}$ of a pumice-rich tuff with heterolithological lithics (lava and plutonic fragments). The top of the SoI is represented by $4-5 \mathrm{~m}$ of a cross-stratified tuff with accretionary lapilli (xsLT) and pumice-rich fragments forming pumice lenses. SoI is the last member of the Altavista Formation, which is still affected by regional faults. Differently from the Altavista formation, the following Tierras Blancas Formation were not deformed by faults of the San Salvador Pull-Apart as shown for example at ILO-20 outcrop, where the TB4 pumice fall rests on an eroded surface at the top of SoI (Figs. 7a, b and c) without any evidence of tectonic deformation.

\subsection{Geochemistry and petrography}

Petrographic and whole-rock chemical analyses were carried out in the six pyroclastic deposits of the Altavista Formation (Table 2). All analyses were performed in pumice clasts, choosing the biggest and freshness clasts available, and discarding the small and the altered pieces. Results indicate that Altavista Formation ignimbrites are evolved felsic calcalkaline rocks from continental-margin subduction zones, confirming the tectonic setting proposed by several authors (Arculus and Curran, 1972; Morris and Ryan, 2004; Murphy, 2007). Petrography indicates a predominant presence of plagioclase, hornblende and clinopyroxene, with small presence of biotite and quartz in some deposits (Table 1 and Fig. 9). Chemical analyses indicate a rhyodacitic composition in all members, with medium to high $\mathrm{K}_{2} \mathrm{O}$ contents (Fig. 10). The multi-element diagram (Fig. 11), which includes the REE concentrations, shows a common magmatic source for the six deposits, with marked anomalies in strontium ( $\mathrm{Sr}$ ) and europium $(\mathrm{Eu})$. Evolved magmas exhibit Eu negative anomalies mainly because of plagioclase fractionation. Plagioclase is the most abundant phenocryst in calcoalkaline magmas, typically dominating over alkali

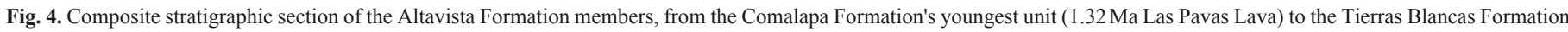
(TB4, <57 ka) of IC. Figure includes the isotopic age of each unit obtained in this study. Lithofacies codes are based on nomenclature from Branney and Kokelaar (2002). 

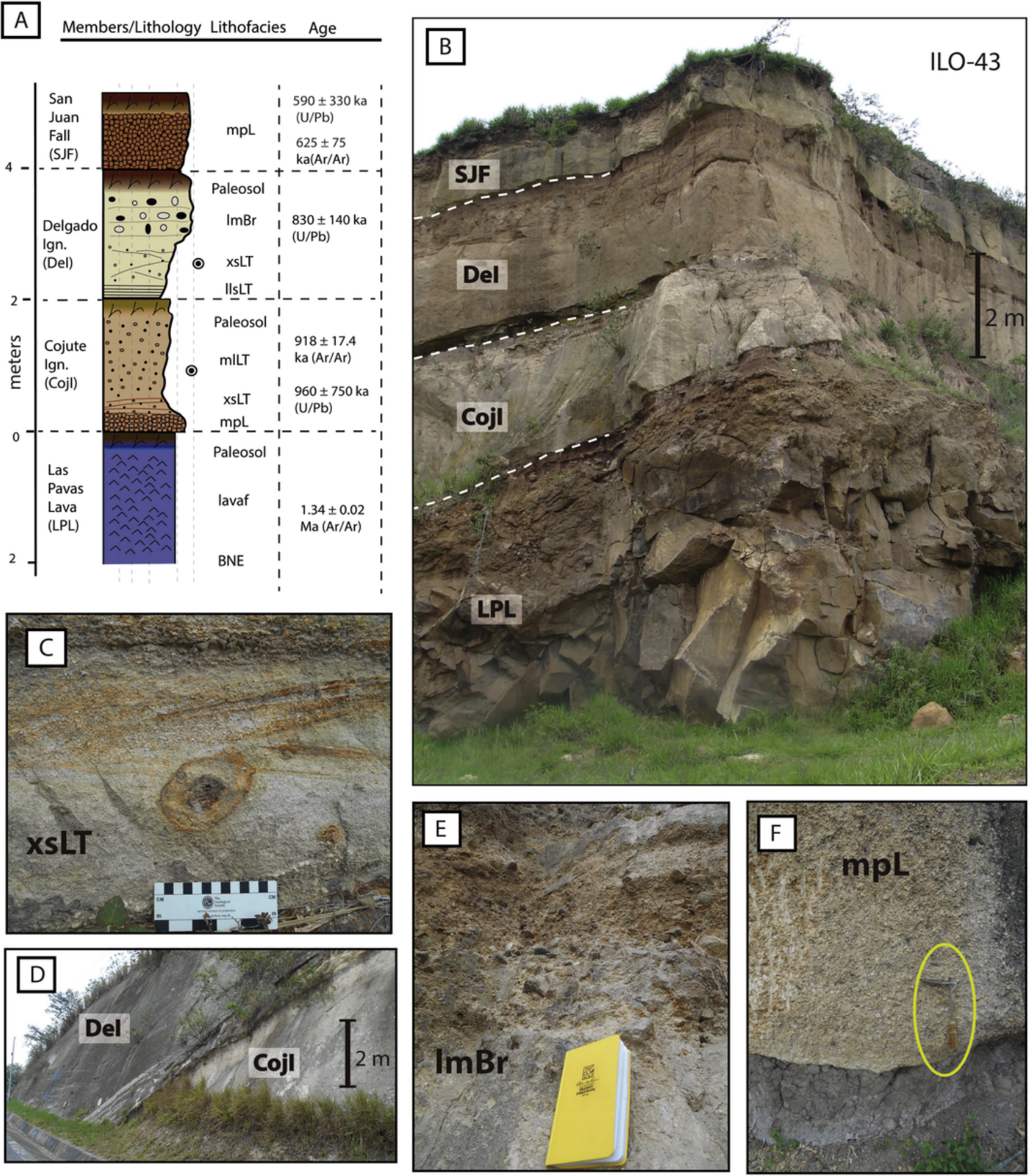

Fig. 5. Stratigraphic volcanic units and representative outcrops along the northeast border of the IC. a) Schematic stratigraphic section of ILO-43 site. For symbols refer to Fig. 4 . b) Site ILO-43, a quarry near Cojutepeque City, where it is possible to observe several members of the Altavista Formation of Ilopango Group overlying Las Pavas Lava (LPL). c) Cross-stratified lapilli tuff in Cojutepeque Ignimbrite (CojI), showing oxidized levels (xsLT, ILO-144 site). d) Delgado Ignimbrite (DeI) on the top of the CojI (ILO-132 site). e) Massive lithic breccia of the DeI. f) Pumice fallout at the base of the CojI (ILO-144 site).

Table 1

Mineral percentages (\%) of the Altavista Formation tuff of the Ilopango Group.

\begin{tabular}{lllllll}
\hline Unit & Plagioclase & Hornblende & Clinopyroxene & Quartz & Biotite & Fe-Ti oxides \\
\hline Soyapango Ign. & 93 & 0 & 0 & 0 & 0 & 7 \\
Cortés Ign. & 84 & 0 & 0 & 3 & 4 & 9 \\
San Juan Fall & 67 & 17 & 4 & 0 & 0 & 12 \\
Manigua Ign. & 72 & 12 & 0 & 5 & 0 & 6 \\
Delgado Ign. & 61 & 18 & 9 & 0 & 0 & 8 \\
Cojutepeque Ign. & 70 & 13 & & & \\
\hline
\end{tabular}



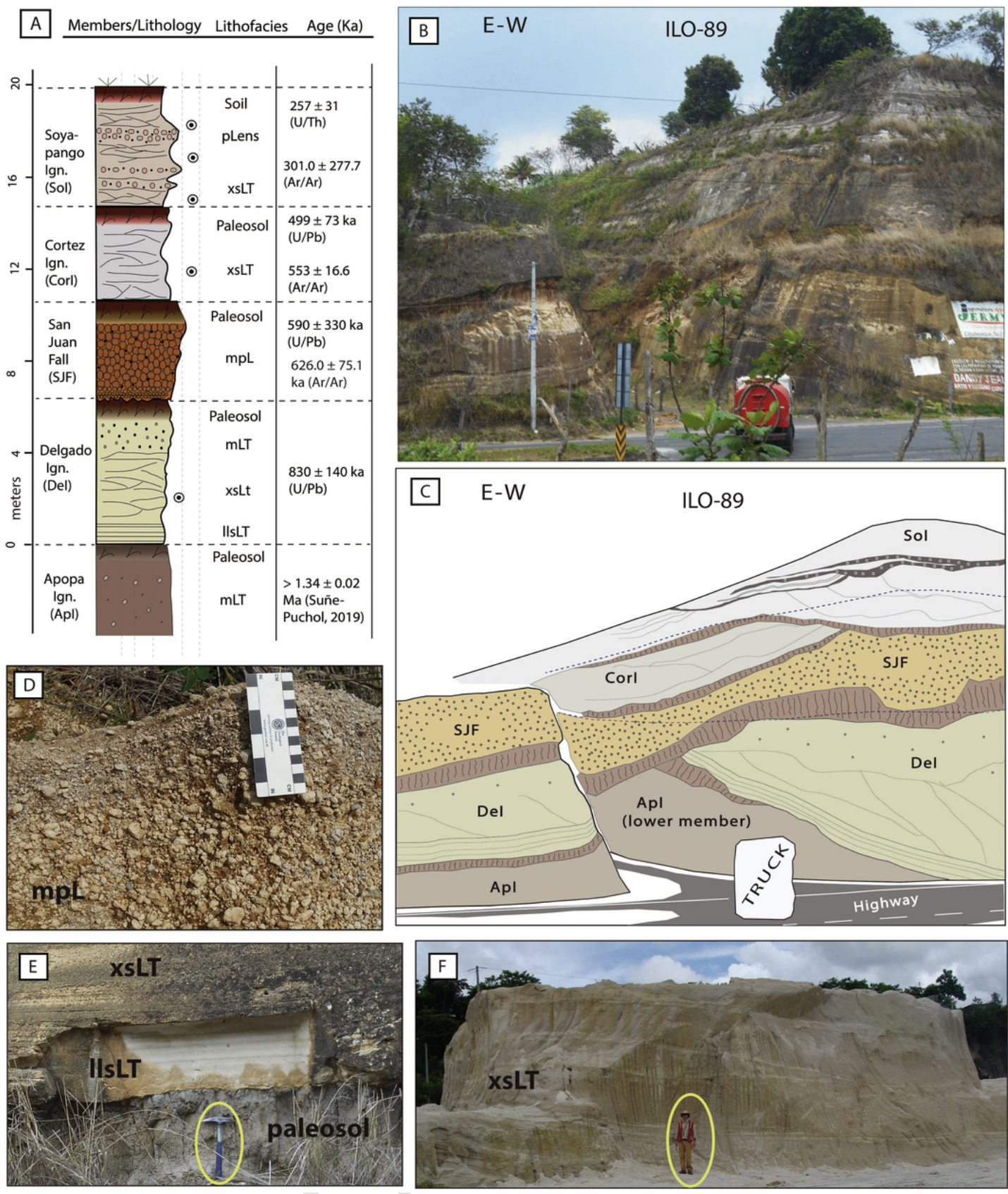

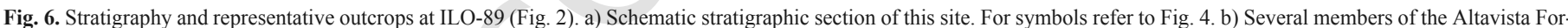

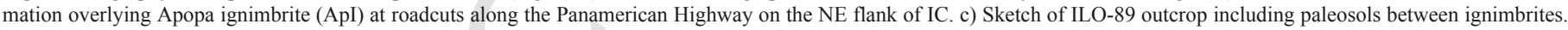

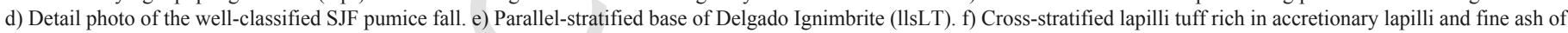
DeI (xsLT).

feldspar (Murphy, 2007), as occurs in the IC products. The most silicic ignimbrites of the Altavista Formation are ManI and DeI, which contain primary bipyramidal quartz. Secondary quartz is common in all members of IC, and was formed during vapour phase silicification in pumice vesicles and open spaces within ash matrix.

\subsection{Geochronology of the Altavista Formation}

A complete set of new isotopic ages of the Altavista Formation is provided in this study in order to have, for the first time, a more detailed volcanic history of IC.

\subsubsection{Results of U/Pb and U/Th analysis}

Six samples of zircon-separates that encompass the entire stratigraphic section of Altavista Formation were prepared to determine the age of each tuff-forming eruption. The first five members of the Altavista Formation were analyzed by $\mathrm{U} / \mathrm{Pb}$ methods and only the last member was done by U/Th. Ages of the first five deposits were calculated with the intersection of the Concordia curve and the normal isochron (Figs. 12a, b, d and e), using the Isoplot software v. 3. 7, and following methods of Ludwig (2008). For ManI, the age was obtained as the average of the non-inherited zircons ages (Fig. 11c). SoI 

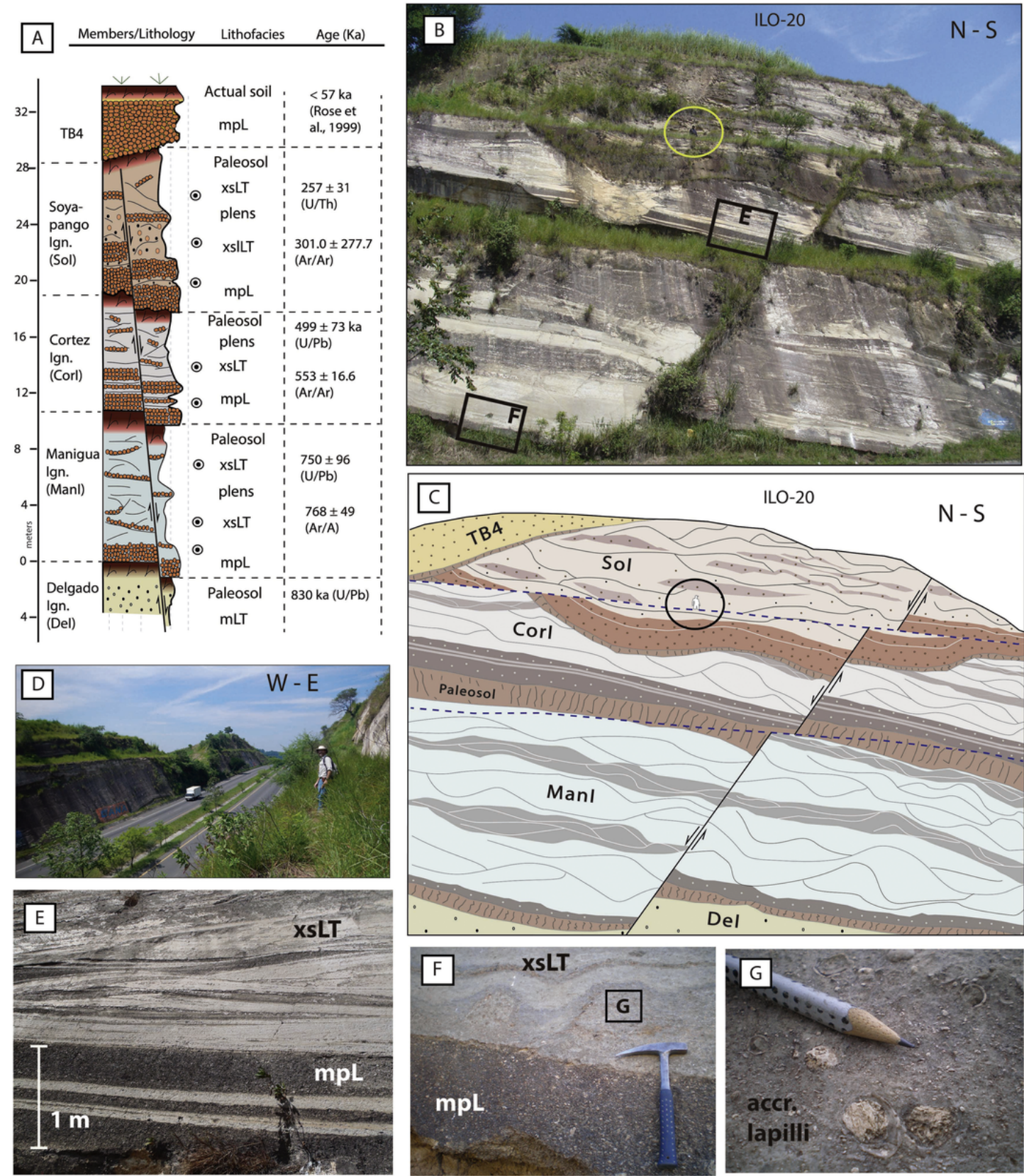

Fig. 7. Stratigraphy and representative outcrops of ILO-20 (Fig. 2). a) Schematic stratigraphic section of this site. b) ILO-20 site at roadcut in Panamericana Highway on the NW flank of IC (note the person to scale, yellow circle). c) Sketch of ILO-20 outcrop including paleosols between ignimbrites and the regional faults affecting the deposits of Altavista Formation (note the person to scale, yellow circle). d) Oblique view of ILO-20 outcrop showing the terraces of the Staircase site. e) Detail photo of pumice fall at the base of CorI with two interbedded surges and cross-stratified lapilli tuff (xsLT) deposited from dilute PDCs. f) Detail of the pumice fall at the base of ManI with hydromagmatic overlying surge PDC deposit, and g) detail photo of accretionary lapilli from the xsLT of Manigua Ignimbrite (ManI). (For interpretation of the references to colour in this figure legend, the reader is referred to the web version of this article.)

age (Figs. 12f) was calculated using IntCal09 software (Reimer et al., 2009), to calibrate U/Th ages (Bernal et al., 2014).

The first member of the Altavista Formation, CojI, is dated at $960 \pm 750 \mathrm{ka}$ (Fig. 12a). The large error is caused probably because most analyzed zircons were too small $(<80 \mu \mathrm{m})$, with xenocrystic cores and concentric zoning, and also due to the limitations of the $U$ $-\mathrm{Pb}$ method in such young zircons (all the errors of $\mathrm{U} / \mathrm{Pb}$ reported in this study refer to $2 \sigma$ standard deviation). To obtain the best possible results, we discarded the most discordant zircons (largest ellip- soids in the isochron diagram, Fig. 12). The second member of this formation, the widespread DeI, is dated at $830 \pm 140 \mathrm{ka}$ (Fig. 12b). The third member, ManI, is dated at $750 \pm 96 \mathrm{ka}$ (Fig. 12c). The fourth member of this formation, SJF, yielded an U/Pb age of $590 \pm 330 \mathrm{ka}$ (Fig. 12d). The fifth member, CorI, yielded an age of $499 \pm 73 \mathrm{ka}$ (Fig. $12 \mathrm{~d})$. SoI, the youngest member of Altavista Formation, yielded an U/ Th age of $257 \pm 33 \mathrm{ka}$ (Fig. 12f). All zircons age data are compiled in Appendix C. 

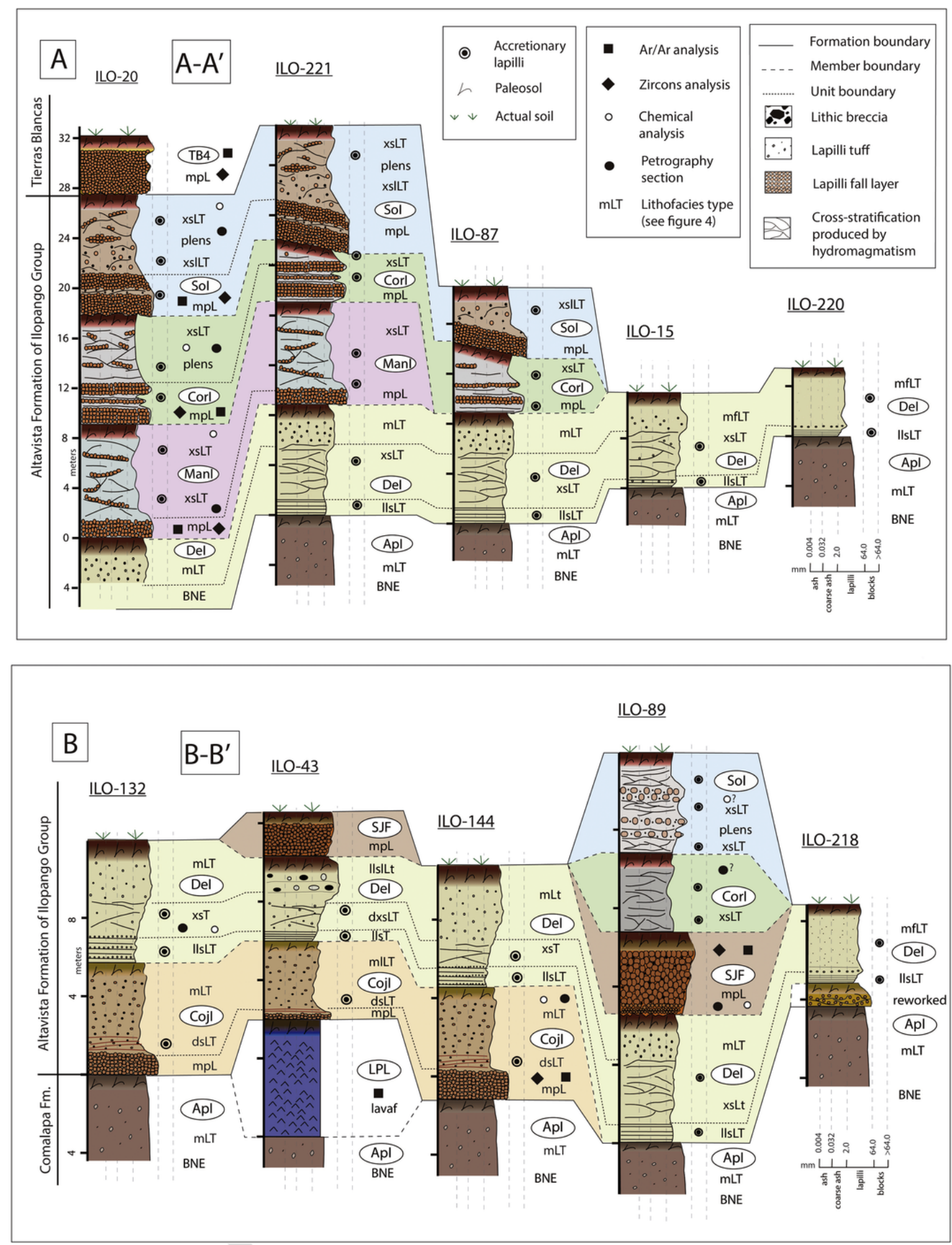

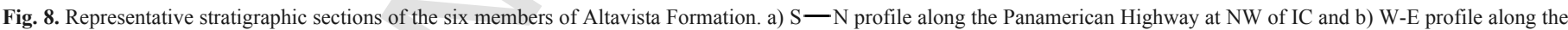
same road on the NE flank of the caldera. ILO localities and stratigraphic sections are shown in Fig. 2.

\subsubsection{Results of ${ }^{40}$ Ar ${ }^{39}$ Ar analyses}

Five new ${ }^{40} \mathrm{Ar} /{ }^{39} \mathrm{Ar}$ ages were performed to obtain a second set of results for comparison and to get more precise age constraints (Table 3 and Fig. 13). Four high-purity plagioclase and one hornblende separates were analyzed. Plagioclase of CojI (sampled at ILO-144, Fig. 3 ) yielded a flat plateau with an age of $918.8 \pm 17.4 \mathrm{ka}$ (Fig. 13a). This ${ }^{40} \mathrm{Ar} /{ }^{39} \mathrm{Ar}$ age for CojI improves the U
- $\mathrm{Pb}$ results presented above showing a smaller error. Plagioclase and hornblende separates of DeI did not yield meaningful ${ }^{40} \mathrm{Ar} /{ }^{39} \mathrm{Ar}$ ages due to the large abundance of atmospheric argon; thus, the $\mathrm{U}$ $-\mathrm{Pb}$ age is the best one we have for this member, although with a large analytical error (Fig. 12b). The plagioclase concentrate analyzed for ManI pumice yielded a ${ }^{40} \mathrm{Ar} /{ }^{39} \mathrm{Ar}$ age of $768.3 \pm 49.4 \mathrm{ka}$. The age spectrum was discordant whose shape is classic "shaddle-shaped" type (Fig. 13c), which prob- 

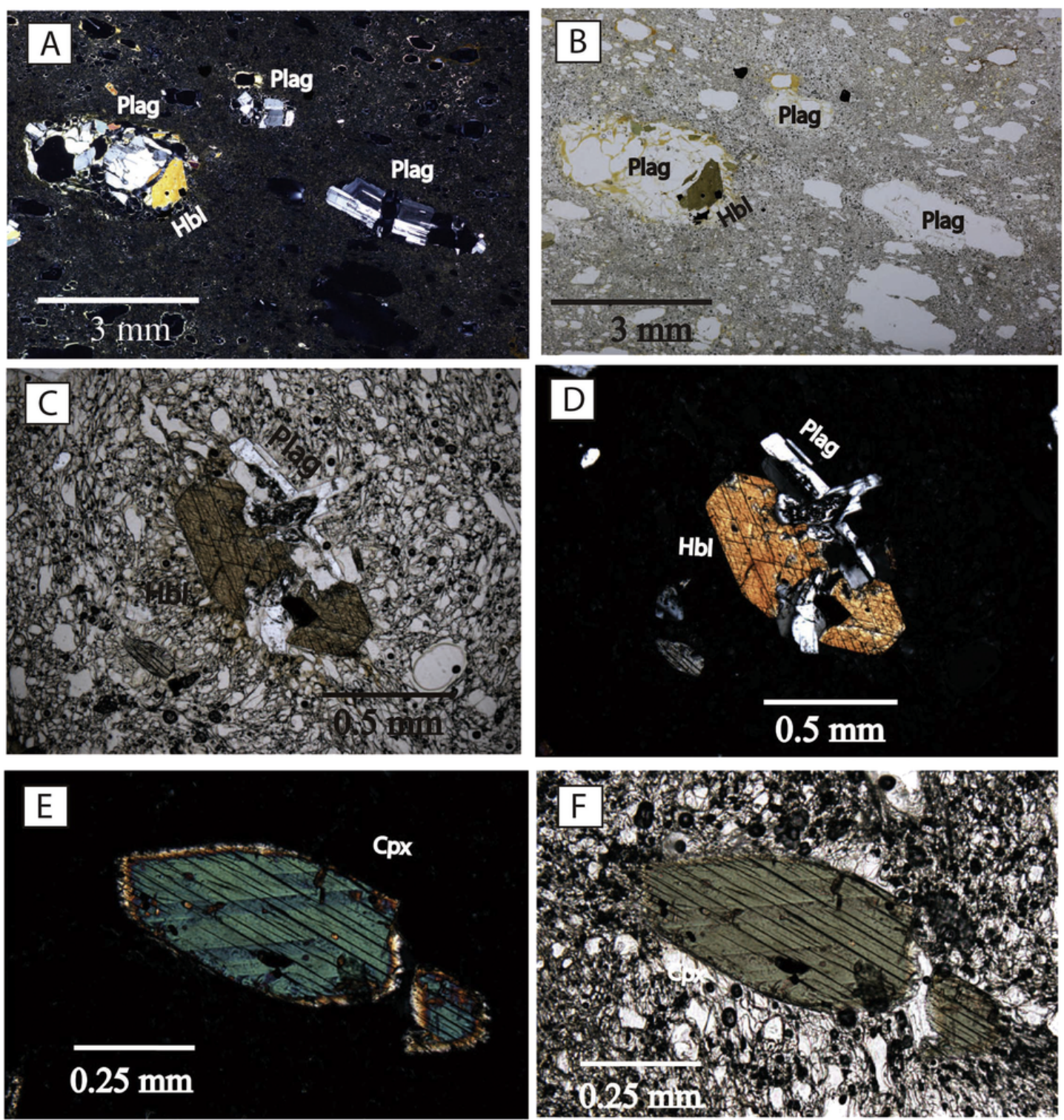

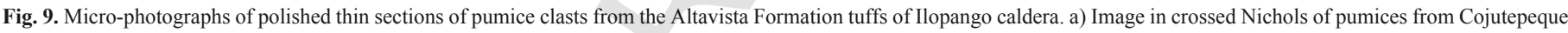

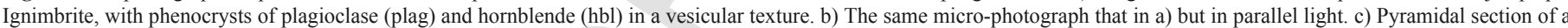

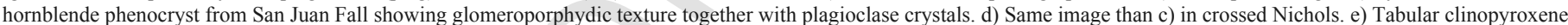
$(\mathrm{cpx})$ of egirine from San Juan Fall (image in crossed Nichols). f) The same egirine of e) in parallel light.

ably represents a mix of excess and atmospheric argon. This ${ }^{40} \mathrm{Ar} /{ }^{39} \mathrm{Ar}$ age agrees with the $\mathrm{U}-\mathrm{Pb}$ results obtained with zircons (Fig. 11c). SJF's age was calculated on hornblende phenocrysts because the plagioclase contained numerous melt inclusions throughout $99 \%$ of the grains, yielding a ${ }^{40} \mathrm{Ar} /{ }^{39} \mathrm{Ar}$ plateau age of $626.0 \pm 75.1 \mathrm{ka}$ (Fig. 13d). CoI's age was obtained from the analysis of a plagioclase separate, yielding a plateau age of $553.0 \pm 16.6 \mathrm{ka}$ (Fig. 13e). The ${ }^{40} \mathrm{Ar} /{ }^{39} \mathrm{Ar}$ analyses of this fifth member constrain better the age obtained by $\mathrm{U}-\mathrm{Pb}$ (Fig. 12e). Sol's age includes only few small plagioclase crystals, which resulted in low quantities of gas and higher uncertainties for many of the heating steps. We chose the upper heating steps that were the most concordant that yielded a weighted mean age of $335 \pm 302.1 \mathrm{ka}$ (Fig. 13f). A list of all ${ }^{40} \mathrm{Ar} /{ }^{39} \mathrm{Ar}$ age (plateau, mini-plateau, total fusion, normal and inverse isochron ages), as well as MSWD's and $\mathrm{K} / \mathrm{Ca}$ ratios are given in Table 3.

\section{Discussion}

\subsection{Volcanic phases and eruptive styles of the Altavista Formation tuffs}

The style and eruption dynamics within the Altavista Formation are very diversified. Eruption processes for each one of the six members of this formation were interpreted from their deposits (Fig. 15) and are described below.

1. Cojutepeque Ignimbrite (CojI; $\sim 918 \mathrm{ka})$. The vent of the first eruption of the Altavista Formation that produced the CojI was localized in the NE sector of the caldera, inferred by the distribution of the associated ignimbrite (Figs. 3). The CojI eruption started with a Plinian or Sub-Plinian column (Fig. 14a) that deposited a $2 \mathrm{~m}$ 

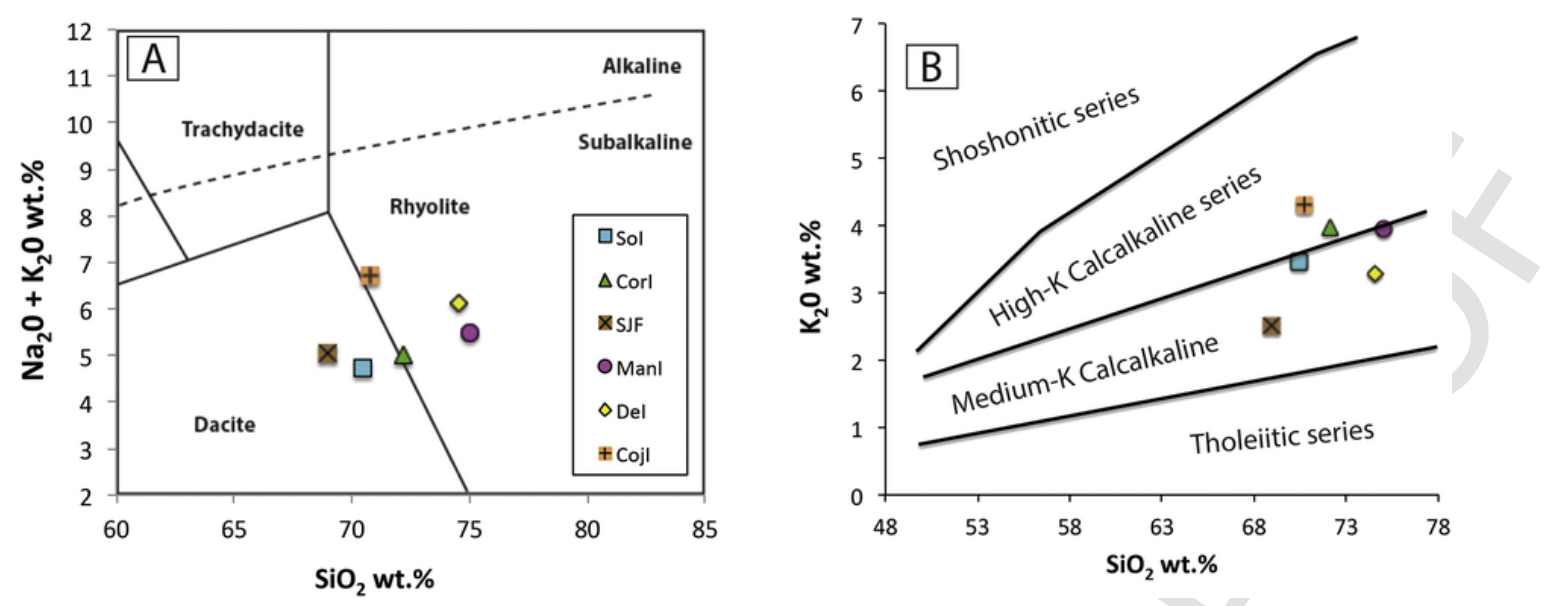

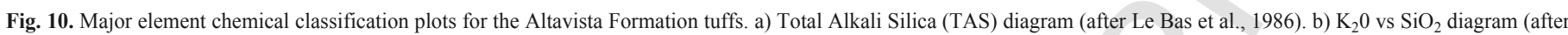
Peccerillo and Taylor, 1976), where is remarkable the High-K content of the Altavista Formation. See Table 2 for chemical data.

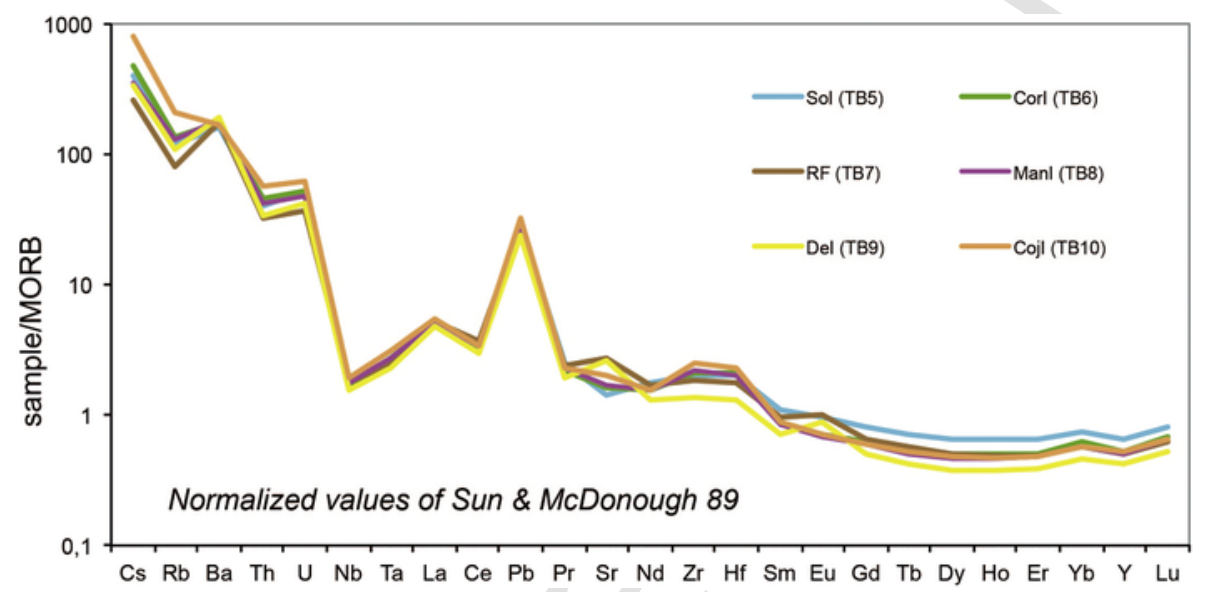

Fig. 11. N-MORB normalized multi-element diagram including of REE abundances of the Altavista Formation tuffs (normalizing values of Sun and McDonough, 1989).

thick pumice fall layer up to $2 \mathrm{~km}$ to the NE of the caldera rim (Figs. 5f). Later, as the sharp contact between this pumice-fallout and the overlying cross-bedded PDC deposit indicates (Fig. 5c), a drastic change in the eruptive style occurred (Fig. 14b). The initial eruptive column collapsed, probably due to the widening of the conduit or by an increase of the mass eruption rate (MER; Costa et al., 2018). This MER increasing could be produced by the beginning of a caldera collapse, which would start the rapid evacuation of magma from the subcaldera magma chamber. The presence of accretionary lapilli (Fisher and Schmincke, 1984), suggests a water-rich environment, likely resulting for the interaction of magma with water from the Ilopango caldera lake. But later, the eruption returned to a magmatic style (Fig. 14c), as inferred by the presence of a massive tuff deposited at the top of CojI, formed by a series of lithic-rich PDC deposits without accretionary lapilli. In fact, the caldera collapse onset likely coincides with the appearance of a lithic-rich PDC. This shift from hydromagmatic to magmatic style could be caused by a high magma/water ratio due to an increase of the magma eruption rate (Wohletz, 1986; Wohletz et al., 2013), probably caused by the caldera collapse. This collapse may have been as trap-door type (Aguirre-Díaz, 2008), due the limited distribution of the associated ignimbrite only present in the NE sector of the caldera (Fig. 3). This interpretation matches with the models of Aguirre-Díaz and Martí (2015); Aguirre-Díaz et al. (2016) and
Saxby et al. (2016), who suggest this kind of collapse mechanism in the past and current IC.

2. Delgado Ignimbrite (DeI; 830 ka). The second eruption of Altavista Formation apparently started with hydromagmatic explosions. This early activity was inferred from the parallel-stratified, fine-rich deposit with accretionary lapilli at the base of DeI (Fig. 6e), probably produced by very dilute PDC's (Fig. 14d). Later on, the hydromagmatic eruption produced highly turbulent PDCs distributed in all directions (Fig. 14e), depositing a widespread cross-stratified tuff, which is richer in solid components and thus apparently derived from denser PDCs than those that formed during the initial blasts (Figs. 3 and 6f). The last phase of this eruption apparently marks a possible change to a magmatic eruptive style, indicated by a lithic-rich level within a massive ignimbrite deposited on the top of this member (Fig. 5e). This kind of lithic-rich zones can be interpreted as a coignimbritic lag breccia suggesting the moment of a caldera collapse (Fig. 14f). Roof collapse of the magma chamber causes a massive and rapid evacuation of magma (Folch and Martí, 2009) that makes less effective the magma-water interactions necessary to carry out hydromagmatic explosions. The caldera collapse could have been the cause of the generation of dry magmatic PDCs at the end of the DeI eruption. The result is a massive and widely distributed ignimbrite sheet (DeI). 

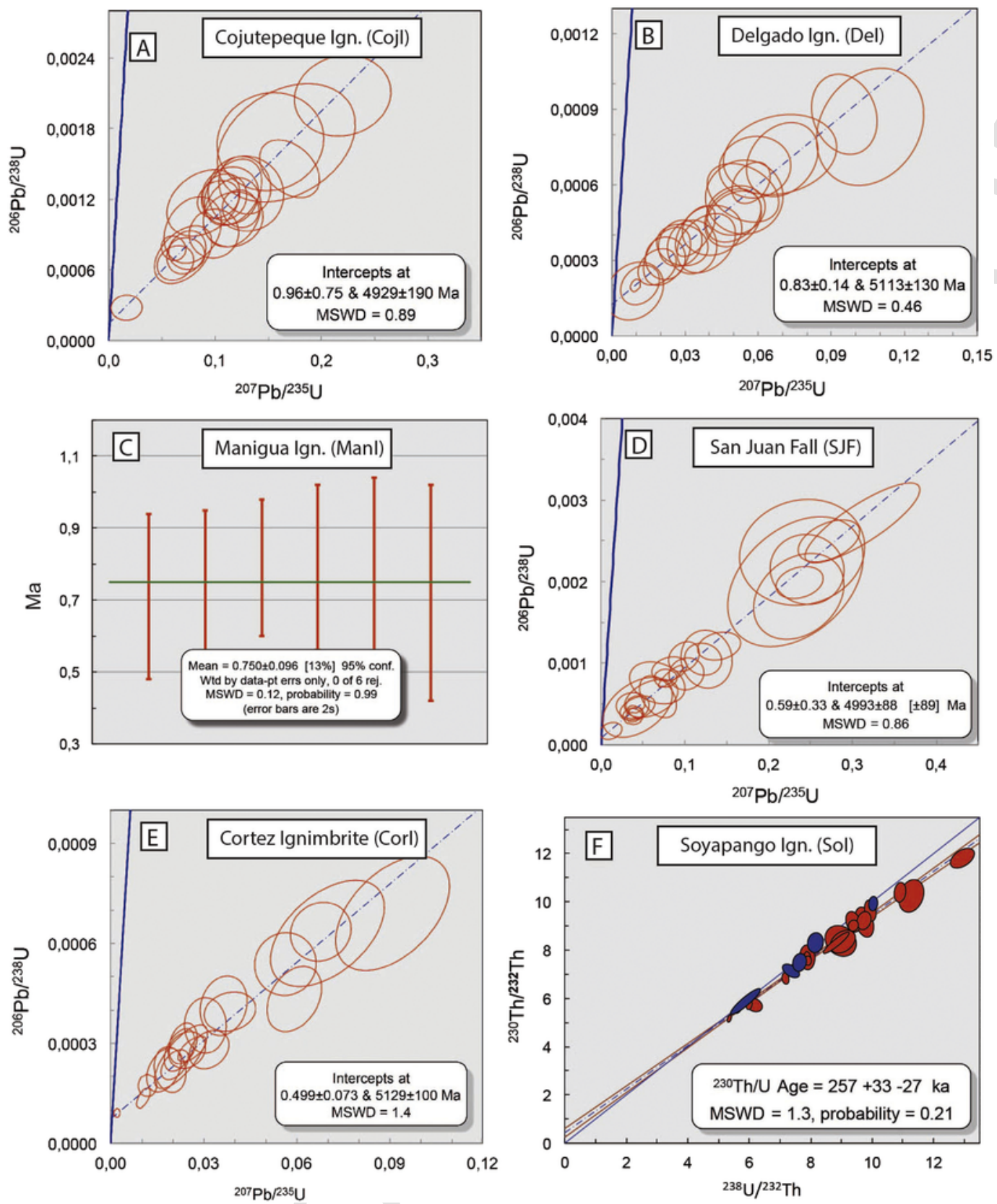

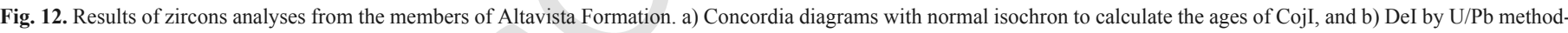

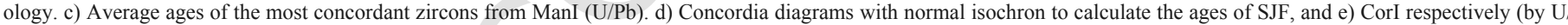

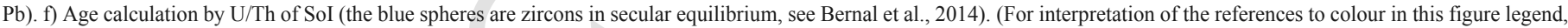
the reader is referred to the web version of this article.)

3. Manigua Ignimbrite (ManI; $\sim 768 \mathrm{ka}$ ). The eruption associated to ManI began as purely magmatic, producing likely an eruptive column (Fig. 14g) that deposited a $30 \mathrm{~cm}$ thick layer of pumice fallout in the NW sector of IC (Fig. 7f). Later, the eruption became hydromagmatic, probably due to the input of water from the paleo-Ilopango lake into the vent, drastically increasing the explosivity of the eruption. The resulting product is a sequence of dilute and cross-bedded PDC deposits, $\sim 8 \mathrm{~m}$ thick, composed of ash matrix and accretionary lapilli, with some thin lens-shape layers rich in pumice fragments (pLens, Fig. 7), which serve as cross-stratification markers. This eruption apparently was laterally directed towards the W-NW flank of the caldera, since the ignimbrite is only observable in this sector of IC (Fig. 3). ManI eruption could be also linked to a partial collapse event, probably with a trap-door collapse style (Fig. 14h) due to the limited distribution of ManI in the eastern sector of the caldera (Fig. 3).

4. San Juan Fall (SJF; $\sim 625 \mathrm{ka}$ ). This member was produced completely by a single eruptive column, probably Plinian or Sub-Plinian type (e.g., Bonadonna and Costa, 2013; Fig. 14i), which formed a thick pumice fallout of 5-6m (Figs. 6d). This eruption was most likely purely magmatic, as no evidence of hydromagmatic processes were found in field exposures. This observation suggests that the vent of the SJF eruption was located outside the paleo-Ilopango lake, and probably in the northeast sector of IC be- 

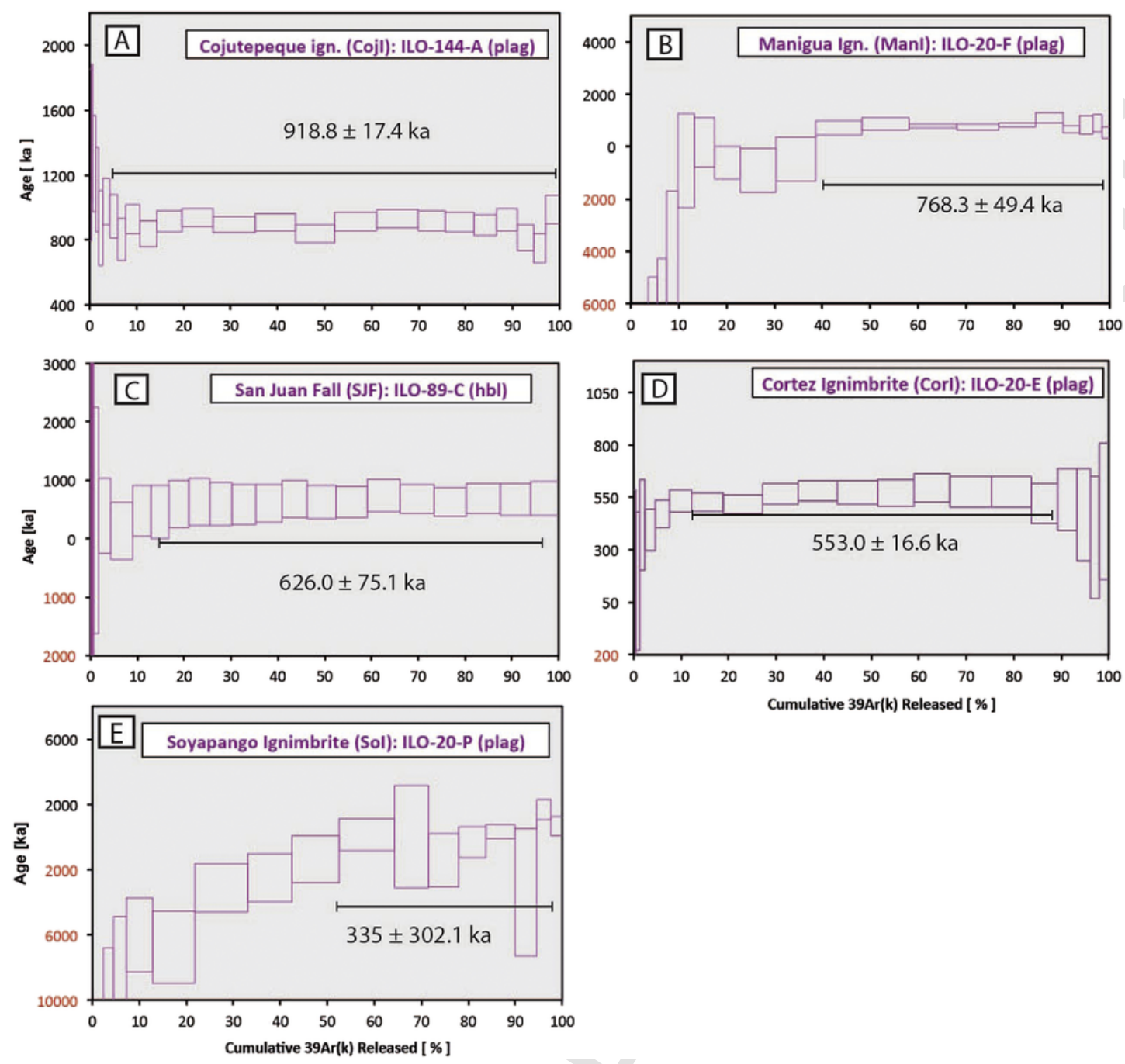

Fig. 13. High-resolution incremental heating ${ }^{40} \mathrm{Ar} /{ }^{39} \mathrm{Ar}$ age spectra for the members of Altavista Formation. The weighted average age $( \pm 2 \sigma)$ is shown above a black bar that indicates the heating steps used in the calculation of a) CojI, b) ManI, c) SJF, d) CorI, and e) SoI ages.

cause SJF is only observable in this direction, near Cojutepeque City (ILO-43, 89 and 316; Fig. 3). This eruption may not have produced a caldera collapse, because there is no associated widespread ignimbrite or other evidence of caldera roof subsidence. As in Las Pavas Lava and other IC products, SJF may have erupted from the outer margin of the caldera, probably from vents controlled by the faults of the pull-apart system that have been linked to previous caldera eruptions of the Comalapa and Altavista Formations (Saxby et al., 2016; Suñe-Puchol et al., 2019).

5. Cortez Ignimbrite (CorI; $\sim 553 \mathrm{ka}$ ). The eruptive processes associated to CorI are very similar to those of the previous ManI member. This eruption started with an eruptive column that deposited a thin layer of pumice fallout ( $<1 \mathrm{~m}$; Fig. 7e). The vent of this eruption may be localized at the northwest sector of the caldera (Fig. 14j), inferred by the distribution of the associated pumice deposit, which is absent at the base of CorI on the northeast flank of IC. The initial eruptive column was suddenly interrupted by hydromagmatic explosions, which deposited a fine-ash tuff with accretionary lapilli derived probably from dilute PDCs (Fig. 14k). We suggest that this eruption was linked to a caldera collapse event based on the relatively large distribution of CorI, which it is still preserved at both flanks of IC (ILO-87, ILO-221 and ILO-20 in the NW sector, and in ILO-89 in the NE sector; Fig. 3).

6. Soyapango Ignimbrite (SoI; $\sim 257 \mathrm{ka}$ ). The last eruption of the Altavista Formation also started with a sustained eruptive column in the NW sector of IC (Fig. 14l), which deposited $>2 \mathrm{~m}$ of pumice fallout as far as $5 \mathrm{~km}$ from the caldera's topographic margin (Figs. 7 and 14l). This phase depressurized the subcaldera magma chamber and could have caused another caldera collapse. In this case, the possible collapse may have been complete along the caldera structure. The eruption style changed from vertical column to low pyroclastic fountaining and radial ejection of dense PDCs (Fig. $14 \mathrm{~m}$ ), overflowing the crater rim and forming a widespread ignimbrite, $\sim 5 \mathrm{~m}$ thick, and observed up to $10 \mathrm{~km}$ from the caldera margin. This ignimbrite is rich in pumice lenses and lithics (heterolitologic). At the final stage, this eruption became slightly hydromagmatic as suggested by the presence of fine-ash particles (higher magma fragmentation) and accretionary lapilli in detriment of larger components, such as pumices and coarser ash matrix, as well as the change from a massive deposit to cross-stratified laminated deposit, although still with pumice-rich lenses. This member crops out on both northern sectors of the caldera (NW and 

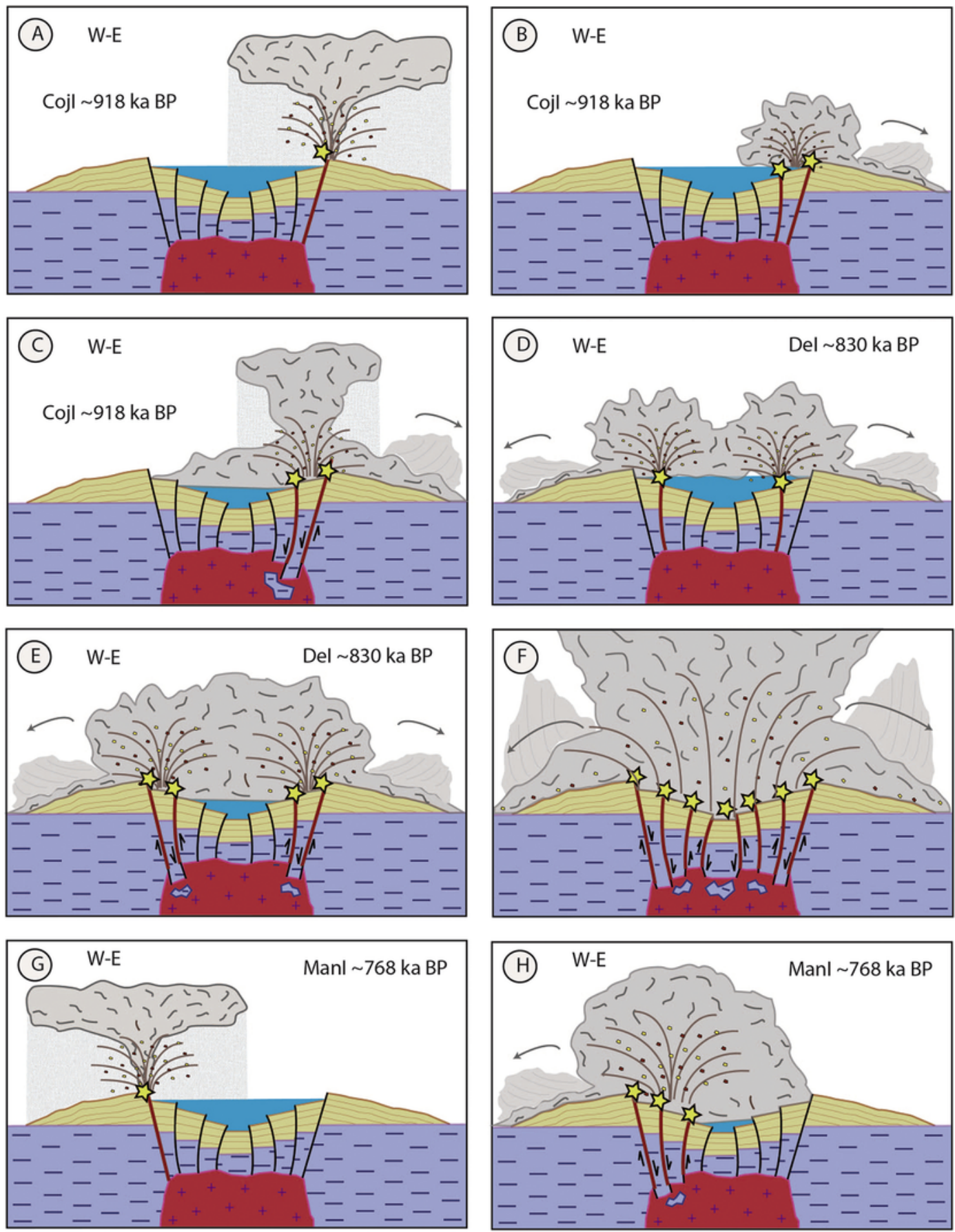

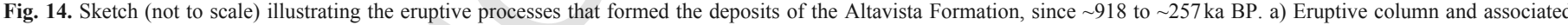

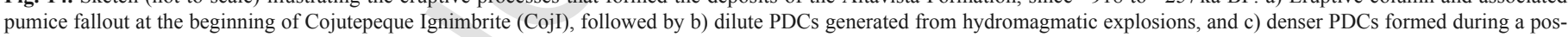

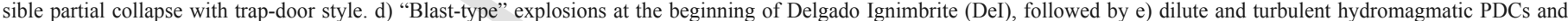

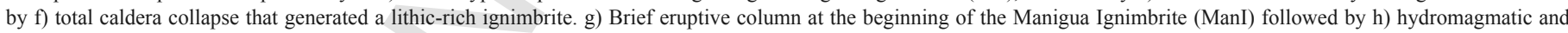

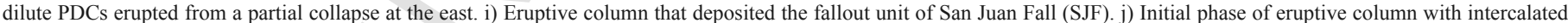

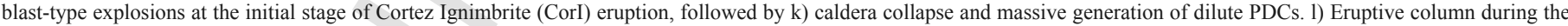
first phase of Soyapango Ignimbrite (SoI)'s eruption followed by $\mathrm{m}$ ) lithic-rich PDCs produced by caldera collapse. 

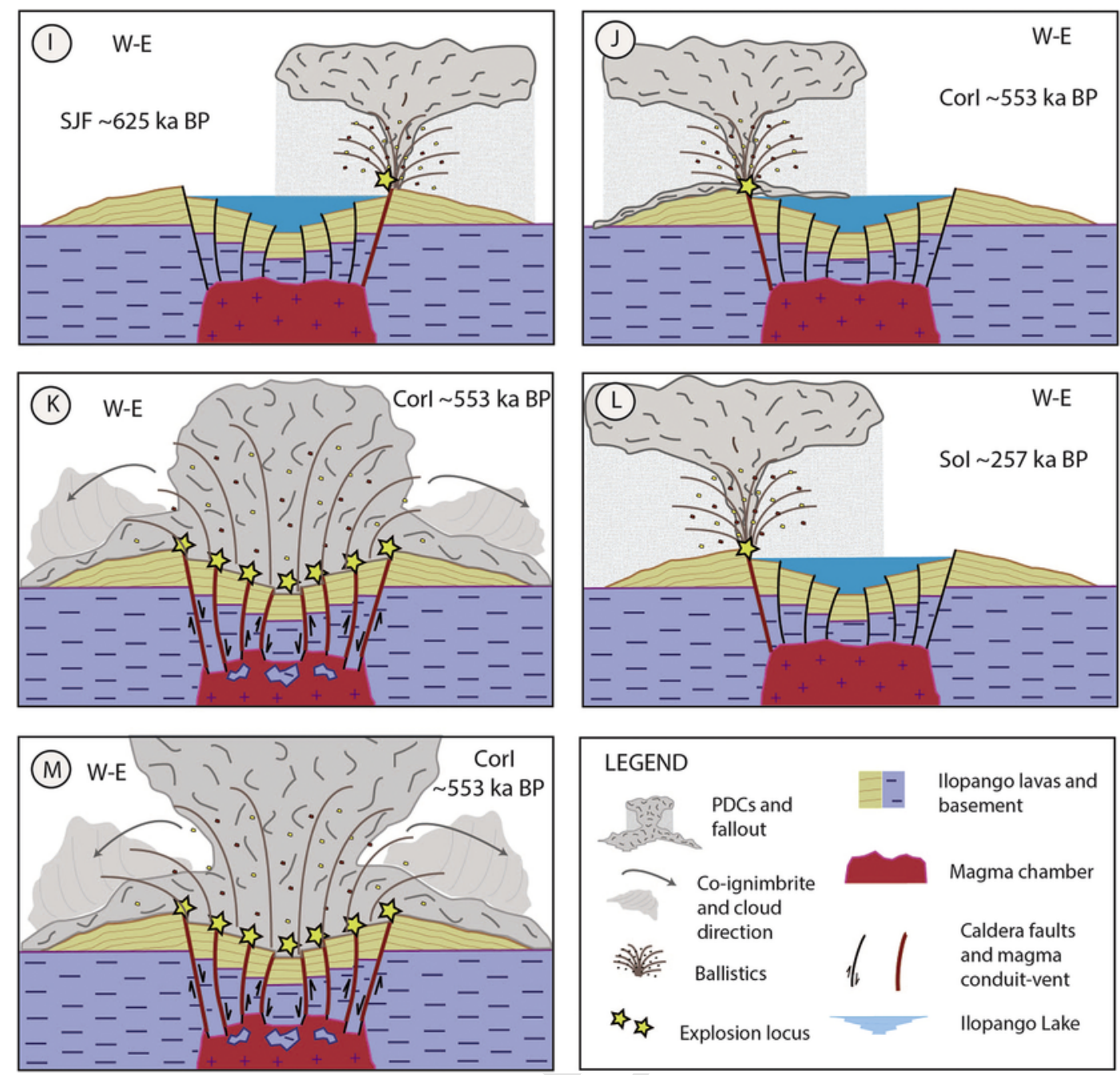

Fig. 14. (Continued)

$\mathrm{NE}$ ), but as in CorI, the pumice-fall layer at the base of the SoI is not evident around the northeast of IC.

\subsection{Volume and eruption magnitude of the Altavista Formation tuffs}

Deposit volumes were calculated applying the Delaunay triangulation method (Macedonio and Pareschi, 1991), by using the thicknesses measured in the field. All data was imported, managed and processed into an attribute table within ArcGIS 10.2 by ESRI $\mathbb{C}$, following methods described in Pitcher et al. (2017). Because of the poor preservation of the Altavista Formation deposits, mainly due to erosion, the corresponding volumes are underestimated. The Delgado Ignimbrite (DeI) was the best member for volume estimation due to its widespread distribution and preservation (Fig. 3). A minimum volume of $5 \mathrm{~km}^{3} \mathrm{DRE}$ was estimated for the DeI. This value corresponds to a magnitude of 6 (Pyle, 2000). This estimation ignores distal ash-fall facies, caldera fill and eroded material over the Balsamo Mountain Range (BMR, southern flank of IC, Fig. 3). Considering that DeI deposits are thicker and more widespread than the TBJ ignimbrite (see Fig. 3), DeI may have had a volume similar to TBJ or even $>40 \mathrm{~km}^{3}$ DRE, reaching a magnitude of 7.

For the other five members of the Altavista Formation, we have established a minimum and conservative estimate, using the thick- nesses and distribution of sparse incomplete outcrops, resulting in the order of 1 to $5 \mathrm{~km}^{3}$ DRE volume for each, which could reach around $30 \mathrm{~km}^{3}$, as those reported for the recent Tierras Blancas tuff-eruptions (CEL, 1992), if the eroded parts are also considered in the estimate.

\subsection{Recurrence period of the Ilopango Caldera explosive eruptions}

The IC has generated at least thirteen explosive eruptions during the Quaternary, most of them ignimbrite-forming events. According to Suñe-Puchol et al. (2019), the first three explosive phases, grouped as the Comalapa Formation, occurred in a time span of $440 \mathrm{ka}$, from $1.78 \mathrm{Ma}$ (1st eruption) to $1.34 \mathrm{Ma}$ (3rd eruption). Those three ignimbrite-forming eruptions had a similar recurrence period of around $220 \mathrm{ka}$ (blue dashed square in Fig. 15). The ${ }^{40} \mathrm{Ar} /{ }^{39} \mathrm{Ar}$ ages presented in this study indicate a long quiescence period between the Comalapa Formation and the first eruption of the Altavista Formation (the CojI eruption, at $\sim 918 \mathrm{ka}$ ). This volcanic hiatus was as large as $\sim 420 \mathrm{ka}$ (Fig. 15). Furthermore, the recurrence period of explosive eruptions within the Altavista Formation is quite shorter than the return time of the first eruptions. This lasted about $100 \mathrm{ka}$ (Fig. 15), which is practically half the time of the frequency of the Comalapa Formation eruptions. 


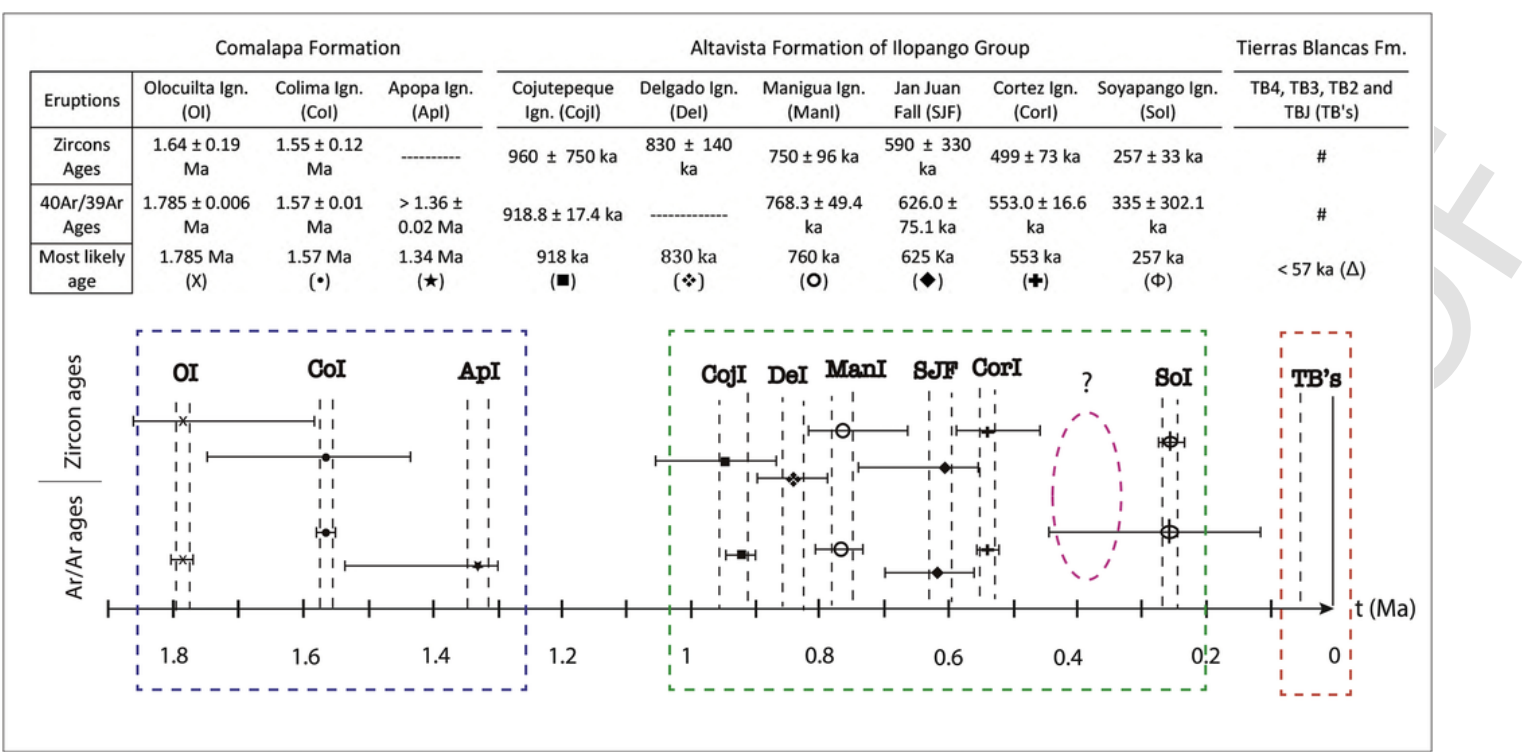

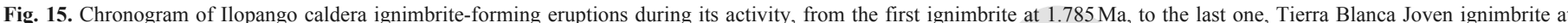

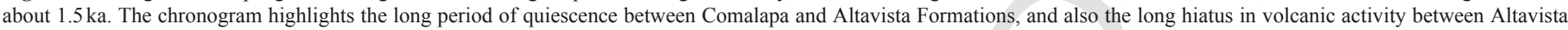

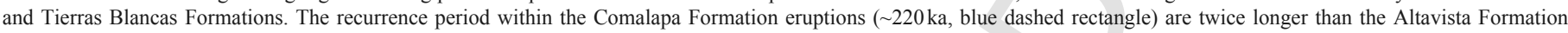

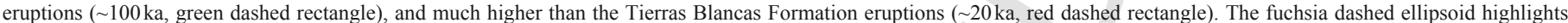

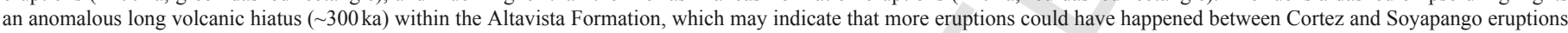
(CorI and, SoI). (For interpretation of the references to colour in this figure legend, the reader is referred to the web version of this article.)

Table 2

Whole-rock chemistry of the Altavista Formation tuffs of Ilopango caldera

\begin{tabular}{|c|c|c|c|c|c|c|}
\hline Sample & ILO-20-P & ILO-20-E & ILO-89-C & ILO-20-F & ILO-132-A & ILO-144-A \\
\hline Unit & SoI(TB5) & CorI (TB6) & SJF (TB7) & ManI (TB8) & DeI (TB9) & CojI (TB10) \\
\hline $\mathrm{SiO}_{2}$ & 70.4 & 72.2 & 69.0 & 75.0 & 74.6 & 70.8 \\
\hline $\mathrm{TiO}_{2}$ & 0.28 & 0.23 & 0.40 & 0.25 & 0.21 & 0.33 \\
\hline $\mathrm{Al}_{2} \mathrm{O}_{3}$ & 18.5 & 17.5 & 17.8 & 14.8 & 13.9 & 16.2 \\
\hline $\mathrm{FeO}^{*}$ & 3.63 & 2.83 & 4.42 & 2.09 & 2.31 & 3.18 \\
\hline $\mathrm{MnO}$ & 0.11 & 0.09 & 0.13 & 0.09 & 0.09 & 0.09 \\
\hline $\mathrm{MgO}$ & 0.58 & 0.61 & 0.77 & 0.69 & 0.65 & 0.74 \\
\hline $\mathrm{CaO}$ & 1.50 & 1.52 & 2.52 & 1.58 & 2.00 & 1.98 \\
\hline $\mathrm{Na}_{2} \mathrm{O}$ & 1.27 & 1.02 & 2.52 & 1.54 & 2.89 & 2.42 \\
\hline $\mathrm{K}_{2} \mathrm{O}$ & 3.48 & 3.99 & 2.51 & 3.94 & 3.29 & 4.31 \\
\hline $\mathrm{P}_{2} \mathrm{O}_{5}$ & 0.04 & 0.04 & 0.05 & 0.03 & 0.04 & 0.03 \\
\hline LOI & 7.29 & 8.62 & 5.29 & 6.80 & 3.81 & 5.08 \\
\hline SUM & 99.8 & 100.1 & 100.0 & 100.2 & 99.9 & 100.1 \\
\hline $\mathrm{Rb}$ & 69 & 115 & 47 & 74 & 66 & 132 \\
\hline $\mathrm{Sr}$ & 139 & 242 & 245 & 152 & 216 & 202 \\
\hline $\mathrm{Ba}$ & 1009 & 864 & 1121 & 1147 & 1171 & 1091 \\
\hline $\mathrm{Y}$ & 20 & 34 & 15 & 13 & 15 & 17 \\
\hline $\mathrm{Zr}$ & 151 & 301 & 137 & 159 & 110 & 193 \\
\hline $\mathrm{Nb}$ & 4 & 14 & 4 & 3 & 4 & 4 \\
\hline V & 27 & 31 & 32 & 21 & 14 & 29 \\
\hline $\mathrm{Cr}$ & $<3$ & 12 & $<3$ & $<3$ & $<3$ & $<3$ \\
\hline $\mathrm{Co}$ & 5 & 8 & 7 & 6 & $<4$ & 8 \\
\hline $\mathrm{Ni}$ & 7 & 13 & 8 & 8 & 7 & 10 \\
\hline $\mathrm{Cu}$ & 23 & 11 & 15 & 13 & 8 & 20 \\
\hline $\mathrm{Zn}$ & 48 & 58 & 44 & 41 & 31 & 45 \\
\hline $\mathrm{Th}$ & 6 & 19 & 4 & 6 & 6 & 10 \\
\hline $\mathrm{Pb}$ & 9 & 22 & 9 & 8 & 8 & 11 \\
\hline$X(m)$ & 266,586 & 266,586 & 292,473 & 266,586 & 287,416 & 289,231 \\
\hline $\mathrm{Y}(\mathrm{m})$ & $1,518,661$ & $1,518,661$ & $1,517,803$ & $1,518,661$ & $1,518,785$ & $1,518,825$ \\
\hline
\end{tabular}

OI: Olocuilta Ignimbrite, CoI: Colima Ignimbrite, ApI: Apopa Ignimbrite.

Major elements in $\mathrm{wt} \%$ and trace elements in ppm.

Samples analyzed by X-Ray Fluorescence in the Instituto de Geología (UNAM) by Patricia Girón.

Coordinates in WGS84 system (zone 16P).

FeO*-total iron; LOI: lost of ignition. 
Table 3

Summary of Incremental Heating 40Ar/39Ar Analyses on Altavista Formation tuffs of Ilopango Caldera.

\begin{tabular}{|c|c|c|c|c|c|c|c|c|c|c|c|c|c|c|c|}
\hline \multicolumn{5}{|l|}{ Sample information } & \multicolumn{6}{|c|}{ Age spectrum } & \multicolumn{2}{|l|}{ Total fusion } & \multicolumn{3}{|c|}{ Inverse isochron analyses } \\
\hline Unit & Sample & $\mathrm{X}(\mathrm{m})$ & $\mathrm{Y}(\mathrm{m})$ & Material & $\mathrm{Age} \pm 2 \sigma(\mathrm{Ka})$ & $39 \operatorname{Ar}(\%)$ & $\mathrm{K} / \mathrm{Ca}$ & MSWD & $\mathrm{n}$ & $\mathrm{N}$ & $\operatorname{Age} \pm 2 \sigma(\mathrm{Ka})$ & $\mathrm{K} / \mathrm{Ca}$ & $\mathrm{Age} \pm 2 \sigma(\mathrm{Ka})$ & $40 / 36$ intercept & MSWD \\
\hline Soyapango Ign. & ILO-20-P & 266,586 & $1,518,661$ & Plagioclase & $335.4 \pm 302.1$ & 33.74 & 0.0232 & 0.81 & 5 & 18 & $2858.0 \pm 512.3$ & 0.0234 & $509.9 \pm 341.8$ & $294.53 \pm 1.44$ & 0.86 \\
\hline Cortez Ign. & ILO-20-E & 266,586 & $1,518,661$ & Plagioclase & $553.0 \pm 16.6$ & 92.40 & 0.0428 & 0.92 & 15 & 20 & $538.0 \pm 20.2$ & 0.0445 & $559.5 \pm 23.3$ & $295.06 \pm 1.21$ & 1.11 \\
\hline San Juan Fall & ILO-89-C & 292,473 & $1,517,803$ & Hornblende & $626.0 \pm 75.1$ & 99.94 & 0.0246 & 0.33 & 24 & 25 & $599.8 \pm 88.6$ & 0.0247 & $679.0 \pm 89.4$ & $291.83 \pm 3.49$ & 0.18 \\
\hline Manigua Ign. & ILO-20-F & 266,586 & $1,518,661$ & Plagioclase & $768.3 \pm 49.4$ & 55.76 & 0.0327 & 1.32 & 9 & 24 & $691.2 \pm 190.7$ & 0.0340 & $768.2 \pm 87.6$ & $297.93 \pm 2.16$ & 2.14 \\
\hline Cojutepeque Ign. & ILO-144-A & 289,231 & $1,518,825$ & Plagioclase & $918.8 \pm 17.4$ & 76.10 & 0.0261 & 0.46 & 13 & 24 & $907.2 \pm 15.7$ & 0.0264 & $910.2 \pm 32.7$ & $316.77 \pm 69.32$ & 0.46 \\
\hline
\end{tabular}

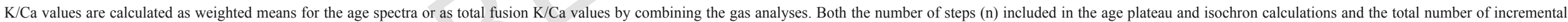

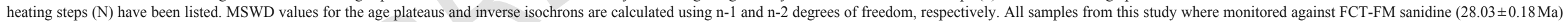
as calibrated by Kuiper et al. (1998). Reported errors on the $40 \mathrm{Ar} / 39 \mathrm{Ar}$ ages are at the $95 \%$ confidence level $(2 \sigma)$ including $0.3-0.4 \%$ standard deviation in the J-value. 
The chronogram of Fig. 15 shows all the IC major explosive eruptions recorded from the stratigraphy and geochronology, by integrating the data of Suñe-Puchol et al. (2019) for the Comalapa Formation, the data of the present work for the Altavista Formation tuffs, and published data elsewhere for the Tierras Blancas Formation (Rose et al., 1999; Kutterolf et al., 2008). Eruption ages of U-Pb, U-Th and ${ }^{40} \mathrm{Ar} /{ }^{39} \mathrm{Ar}$ from our database are positioned along a timescale bar with the corresponding analytical error bars. This chronogram shows a regular periodicity along the Altavista Formation eruptions, except for the time span between CorI ( $\sim 553 \mathrm{ka})$ and SoI $(\sim 257 \mathrm{ka})$, which had a hiatus in the activity of $\sim 300 \mathrm{ka}$ (Fig. 15). In addition, it is evident another relatively long period of volcanic inactivity of $\sim 200 \mathrm{ka}$ between the Altavista and Tierras Blancas formations of IC (Fig. 15).

The most notorious observation from this chronologic chart is the relatively large quiescence periods between each formation, in the order of $200-400 \mathrm{ka}$ each. The meaning of these quiet periods is still not clear, but we assume that the tectonic factor and the magma input rate are the two principal reasons. During the whole IC activity, from 1.78 to present, there was also intense tectonic activity in the area, and a seismogenically active period related to the ESFZ (Garibaldi et al., 2016). As previously reported in Aguirre-Díaz et al. (2016), Saxby et al. (2016), and Suñe-Puchol et al. (2019), the IC volcanic activity was in close relationship with the transtensive tectonic regime of the region, and IC is the result of several episodes of pull-apart-related caldera collapses that were linked to the strike-slip faults of the ESFZ.

IC volcanism, since the initial eruptions to the last one of TBJ $(1.5 \mathrm{ka})$, was, and is tied to the Neogene activity of the regional faults of the central El Salvador region. The recurrence of large explosive eruptions could be linked to tectonic slips and the corresponding displacements between blocks, and probably, these tectonic events were the triggers for large explosive eruptions at IC, if the magma of the subcaldera chamber was close to eruptive conditions.

\section{Conclusions}

Ilopango Caldera (IC) has had at least 13 large Quaternary explosive eruptions, mostly ignimbrite-forming events, which were grouped into three formations, Comalapa Formation (1.78-1.32 Ma), Altavista Formation (918-257 ka) and Tierras Blancas Formation ( $<57 \mathrm{ka})$.

The Altavista Formation, presented in this study for the first time, consists of ryhodacitic pyroclastic deposits that are the product of six explosive eruptions, including eruptive columns and dense and dilute PDCs of magmatic and hydromagmatic type. The largest member of the Altavista Formation is the Delgado Ignimbrite (DeI), with a minimum DRE volume $>30 \mathrm{~km}^{3}$ if eroded deposits are considered. The recurrence period of the Altavista Formation eruptions is $\sim 100 \mathrm{ka}$, except between the two last events (553 ka CorI and $257 \mathrm{ka} \mathrm{SoI})$. This is half the time of the Comalapa Formation explosive eruptions recurrence period $(\sim 220 \mathrm{ka})$.

A chronostratigraphic chart of all IC eruptions since the initial large Olocuilta ignimbrite $\left(1.78 \mathrm{Ma} ;>150 \mathrm{~km}^{3} \mathrm{DRE}\right)$ to the latest TBJ $\left(\sim 1.5 \mathrm{ka} ; 30 \mathrm{~km}^{3} \mathrm{DRE}\right)$ shows large quiescence gaps of nearly 200 to $400 \mathrm{ka}$ between major eruptive members. These long quiet gaps and intense activity within each formation are apparently linked with the transtensive tectonic activity of the ESFZ. IC is the result of several caldera collapse episodes, each for a major ignimbrite eruption, which were probably triggered by tectonic events, although this complex relation needs to investigated further.

Supplementary data to this article can be found online at https:// doi.org/10.1016/j.jvolgeores.2019.02.011.

\section{Uncited references}

Alvarenga et al., 2001

Bosse et al., 1978

Koppers et al., 2003

LaFemina et al., 2009

Min et al., 2000

Steiger and Jäger, 1977

Taylor, 1977

York, 1969

\section{Acknowledgements}

This study was financed by CONACYT-CB grant 240447 to GJAD. We appreciate the logistical support of the Ministerio de Medio Ambiente y Recursos Naturales - MARN, and of the Policia Nacional Civil - PNC, of El Salvador. We thank the doctoral scholarship grant to the first author from CONACYT-Mexico. We acknowledge to Anthony Koppers for his help and support in the Ar/Ar geochronology laboratory at Oregon State University (OSU). We want to be grateful to Juan Vazquez for thin section elaboration, to Lozano Santacruz and Patricia Girón for XRF analyses, and Ofelia Perez for the REE and trace elements analyses. We also want to thank Victor Noll for his rappel training to sample the ignimbrites of Ilopango caldera. This manuscript was greatly improved by comments and suggestions from the editors Joan Martí and James Gardner, and also from two experts reviewers.

\section{References}

Agostini, S., Corti, G., Doglioni, C., Carminati, E., Innocenti, F., Tonarini, S., Manetti, P., Di Vincenzo, G., Montanari, D., 2006. Tectonic and magmatic evolution of the active volcanic front in El Salvador: insight into the Berlín and Ahuachapán geothermal areas. Geothermics 35, 368-408. https://doi.org/10.1016/j.geothermics. 2006.05.003.

Aguirre-Díaz, G.J., 2008, Types of collapse calderas: Collapse calderas Workshop 19-25 October 2008, Querétaro, Mexico "Reconstructing the Evolution of Collapse Calderas: Magma Storage, Mobilization and Eruption”. IOP Conference Series: Earth and Environmental Science, 3012021 (5pp) doi:https://doi.org/10.1088/ 1755-1307/3/1/012021 (http://www.iop.org/EJ/toc/1755-1315/3/1

Aguirre-Díaz, G.J., Martí, J., 2015. Graben Calderas: Examples from Mexico, Central America, and the Andes: 26th IUGG General Assembly, Prague, Czech Republic, June 22-July 2, 2015. Abstracts https://www.czech-in.org/cm/IUGG/.

Aguirre-Díaz, G.J., Suñe-Puchol, I., Dávila-Harris, P., Pedrazzi, D., Hernández, W., 2016. The Ilopango Caldera: A Long-Lived Caldera System of Central America: 6th International Workshop on Collapse Calderas, IAVCEI, Hokkaido, Japan; June 2016, (Abstracts).

Aguirre-Díaz, J.G., Suñe-Puchol, I., Davila-Harris, P., Pedrazzi, D., Hernandez, W., Gutierrez, E., 2017. Volcanic History of the Ilopango Caldera, Central American Volcanic Arc. 113th Annual Meeting. GSA Cordilleran Section, Hawaii, USA, 2017.

Alonso-Henar, J., Álvarez-Gõmez, J.A., Martinez-Díaz, J.J., 2017. Neogene-quaternary evolution from transpressional to transtesional tectonics in Northern Central America controlled by cocos: Caribbean subduction coupling change. J. Iber. Geol. https://doi.org/10.1006/s415113-017-0034-2.

Alvarenga, E.R., Hernández, D.A., Hernández-Flores, D.A., 2001. Cronología de sismos destructivos en El Salvador: Servicio Geológico Nacional. Área de Sismología http://www.snet.gob.sv/Geologia/Sismologia/1 crono.htm.

Arculus, R.J., Curran, E.B., 1972. The genesis of the calc-alkaline rock suite. Earth Planet. Sci. Lett. 15, 255-262.

Bernal, J.P., Lozano-Santacruz, R., 2005. Characterization of a new set of eight geochemical reference materials for XRF major and trace element analysis. Revista Mexicana de Ciencias Geológicas 22 (3), 329-344.

Bernal, J.P., Solari, L.A., Gómez-Tuena, A., Ortega-Obregón, C., Mori, L., Vega-González, M., Espinosa-Arbeláez, D.G., 2014. In-situ230Th/U dating of Quaternary zircons using LA-MCICPMS. Quat. Geochronol. 23, 46-55. https:// doi.org/10.1016/j.quageo.2014.06.003.

Bonadonna, C., Costa, A., 2013. Plume height, volume, and classification of explosive volcanic eruptions based on the Weibull function. Bull. Volcanol. 75 (8), 1-19. 
Bosse, H.R., Lorenz, W., Merino, A., Mihm, A., Rode, K., Schmidt-Thome', M., Wiesemann, G., Weber, H.S., 1978. Geological Map of El Salvador Republic. Bundesanstalt für Geowissenschaften und Rohstoffe, D-3. In: scale 1:100,000. Hannover, Germany.

Branney, M.J., Kokelaar, P., 2002. Pyroclastic density currents and the sedimentation of ignimbrites: Geol Soc London. Memoirs 27, (152 pp).

Canora, C., Villamor, P., Martínez-Díaz, J.J., Berryman, K.R., Álvarez-Gómez, J.A., Capote, R., Hernández, W., 2012. Paleoseismic analysis of the San Vicente segment of the El Salvador Fault Zone, El Salvador, Central America. Geol. Acta 10, 103-123. https://doi.org/10.1344/105.000001700.

CEL (Comision Ejecutiva Hidroelectrica del Rio Lempa), 1992. Desarrollo de los Recursos Geotermicos del Area Centro-Occidental de El Salvador. Prefactibilidad Geotermica del Area de Coatepeque. Reconocimiento Geotermico. Informe Final. In: Internal report.

Costa, A., Suzuki, Y.J., Koyaguchi, T., 2018. Understanding the plume dynamics of explosive super-eruptions. Nat. Commun. 9, 654. https://doi.org/10.1038/ s41467-018-02901-0.

DeMets, C., 2001. A new estimate for present-day Cocos-Caribbean plate motion: Implications for slip along the Central American volcanic arc. Geophys. Res. Lett. 28, 4043-4046. https://doi.org/10.1029/2001GL013518.

Dixon, T.H., 1993. GPS measurement of relative motion of the Cocos and Caribbean plates and strain accumulation across the Middle America Trench. Geophys. Res. Lett. 20, 2167-2170. https://doi.org/10.1029/93GL02415.

Donnelly, T.W., Horne, G.S., Finch, R.C., Lopez-Ramos, E., 1990. Northern Central America: the Maya and Chortis blocks. In: Dengo, G., Case, J.E. (Eds.), The Geology of North America: The Caribbean Region. pp. 37-76.

Dull, R.A., Southon, J.R. and Sheets, P., 2001. Volcanism, Ecology and Culture: A Reassessment of the Voclán Ilopango TBJ eruption in the Southern Maya Realm, v. 12, No. 1, pp. 25-44.

Dull, R.A., Southon, J.R., Kutterolf, S., Freundt, a., Wahl, D., Sheets, P., 2010. Did the TBJ Ilopango eruption cause the AD 536 event? AGU fall Meet. Abstr. 1, 2370

Fisher, R.V., Schmincke, H.-U., 1984. Pyroclastic Rocks: Berlin. Springer Verlag, (472 p).

Folch, A., Martí, J., 2009. Time-dependent chamber and vent conditions during explosive caldera-forming eruptions. Earth Planet. Sci. Lett. https://doi.org/10.1016/j. eps1.2009.01.035.

Funk, J., Mann, P., McIntosh, K., Stephens, J., 2009. Cenozoic tectonics of the Nicaraguan depression, Nicaragua, and Median Trough, El Salvador, based on seismic-reflection profiling and remote-sensing data. Bull. Geol. Soc. Am. 121, 1491-1521. https://doi.org/10.1130/B26428.1.

Garibaldi, N., Tikoff, B., Hernández, W., 2016. Neotectonic deformation within an extensional stepover in El Salvador magmatic arc, Central America: Implication for the interaction of arc magmatism and deformation. Tectonophysics 693, 327-339. https://doi.org/10.1016/j.tecto.2016.05.015.

Golombek, M.P., Carr, M.J., 1978. Tidal triggering of seismic and volcanic phenomena during the 1879-1880 eruption of Islas Quemadas volcano in El Salvador, Central America. J. Volcanol. Geotherm. Res. 3, 299-307. https://doi.org/10.1016 0377-0273(78)90040-9.

Hernández, E.W., 2004, Características geotécnicas y vulcanológicas de las tefras de Tierra Blanca Joven de Ilopango, El Salvador: Tesis de maestría, Univ. Politécnica de El Salvador, San Salvador, $115 \mathrm{p}$

Hernández, W., 2008, Aspectos geológicos que influyen en las aguas subterráneas y en la respuesta sísmica del Area Metropolitana de San Salvador. Revista ASIA No. 162. 29-41p.

Hutton, D.H.W., Reavy, R.J., 1992. Strike-slip tectonics and granite petrogenesis. Tectonics $11,960-967$

Koppers, A.A.P., 2002. ArArCALC—Software for 40Ar/39Ar age calculations. Comput. Geosci. 28 (5), 605-619. https://doi.org/10.1016/S0098-3004(01)00095-4

Koppers, A., Staudigel, H., Wijbrans, J.R., Pringle, M., 2003. Short-lived and discontinuous intraplate volcanism in the South Pacific: Hot spots or extensional volcanism?. Geochem. Geophys. Geosyst. 4, https://doi.org/10.1029/2003GC000533.

Koppers, A.P., Gowen, M.D., Colwell, L.E., Gee, J.S., Lonsdale, P.F., Mahoney, J.J., Duncan, R.A., 2011. New 40Ar/39Ar age progression for the Louisville hot spot trail and implications for inter-hot spot motion. Geochem. Geophys. Geosyst. 12: Q0AM02. doi:https://doi.org/10.1029/2011GC003804.

Kuiper, K.F., Deino, A., Hilgen, F.J., Krijgsman, W., Renne, P.R., Wijbrans, J.R., 2008. Synchronizing rock clocks of Earth history. Science 320, 500-504. https:// doi.org/10.1126/science.1154339.

Kutterolf, S., Freundt, A., Schacht, U., Bürk, D., Harders, R., Mörz, T., Peréz, W., 2008. Pacific offshore record of plinian arc volcanism in Central America: 3. Application to forearc geology. Geochem. Geophys. Geosyst. 9, https://doi.org/10. 1029/2007GC001826.

LaFemina, P., Dixon, T.H., Govers, R., Norabuena, E., Turner, H., Saballos, A., Mattioli, G., Protti, M., Strauch, W., 2009. Fore-arc motion and Cocos Ridge collision in Central America. Geochem. Geophys. Geosyst. 10, https://doi.org/10.1029/ 2008 GC002181.
LeBas, et al., 1986. A chemical classification of volcanic rocks based on the total alkali-silica diagram. J. Petrol. 27, 745-750.

Lexa, J., Šebesta, J., Chavez, J.A., Hernández, W., Pécskay, Z., 2011. Geology and volcanic evolution in the southern part of the San Salvador Metropolitan Area. J. Geosci. 56, 105-140. https://doi.org/10.3190/jgeosci.088.

Ludwig, K. 2008. Manual for Isoplot 3.7. Berkeley Geochronology Center, Special Publication 4, rev. p. 77.

Macedonio, G., Pareschi, M.T., 1991. An algorithm for the triangulation of arbitrarily distributed points: applications to volume estimate and terrain fitting. Comput. Geosci. 17, 859-874. https://doi.org/10.1016/0098-3004(91)90086-S.

Mann, P., 2007. Overview of the tectonic history of northern Central America. In: Mann, P. (Ed.), Geologic and Tectonic Development of the Caribbean Plate Boundary in Northern Central America. 428, Geological Society of America Special Papers, pp. 1-19.

Marshall, D.J., 1988. Cathodoluminescence of Geological Materials. Unwin Hyman, 181

Martí, J., Groppelli, G., \& da Silveira, A. B., 2018. Volcanic stratigraphy: a review. J. Volcanol. Geotherm. Res. Volume 357, 15 May 2018, Pages 68-91.

Martínez-Díaz, J.J., Álvarez-Gómez, J.A., Benito, B., Hernández, D., 2004. Triggering of destructive earthquakes in El Salvador. Geology 32, 65-68. https://doi.org/10. 1130/G20089.1.

Min, K., Mundil, R., Renne, P.R., Ludwig, K.R., 2000. A test for systematic errors in 40Ar/39Ar geochronology through comparison with $\mathrm{U} / \mathrm{Pb}$ analysis of a $1.1-\mathrm{Ga}$ rhyolite. Geochim. Cosmochim. Acta 64, 73-98.

Morris, J.D., and Ryan, J.G, 2004, Subduction zone processes and implications for changing composition of the upper and lower mantle, in Treatise on Geochemistry, ed., H.D. Holland and K.K. Turekian, Elsevier-Pergamon, Oxford, p. 451-470.

Murphy, J.B., 2007. Igneous Rock Associations 8. Arc Magmatism II: Geochemical and Isotopic Characteristics. Geosci. Can. 34, 1

Ortega-Obregón, C., Solari, L., Gómez-Tuena, A., Elías-Herrera, M., Ortega-Gutiérrez, F., Macías-Romo, C., 2013. Permian-Carboniferous arc magmatism in southern Mexico: $\mathrm{U}-\mathrm{Pb}$ dating, trace element and $\mathrm{Hf}$ isotopic evidence on zircons of earliest subduction beneath the western margin of Gondwana. Int. J. Earth Sci. 103 (5), 1287-1300. https://doi.org/10.1007/s00531-013-0933-1.

Peccerillo, A., Taylor, S.R., 1976. Geochemistry of Eocene calcalkaline volcanic rocks from the Kastamonu area, Northern Turkey. Contrib. Mineral. Petrol. 58, 63-81.

Pedrazzi, D., Sunyé-Puchol, I., Aguirre-Díaz, G.J., Costa, A., Davila-Harris, P., Hernández, W., Gutierrez, E., 2018. The Ilopango Tierra Blanca Joven (TBJ) eruption, El Salvador: volcano-stratigraphy of a major Holocene event of Central America and hazards implications EGU General Assembly 2018. Vol. 20, EGU2018-8455.

Pitcher, B. W., Kent, A.J.R, Grunder, A.L. and Duncan, R.A., Frequency and volumes of ignimbrite eruptions following the Late Neogene initiation of the Central Oregon High Cascades. J Volcanol Geotherm Res 339: 1-22, doi:10.1016/j.jvolgeores.2017.04.019.

Pyle, D.M., 2000. The sizes of volcanic eruptions. In: Sigurdsson, H., Houghton, B., McNutt, S.R., Rymer, H., Stix, J. (Eds.), Encyclopedia of Volcanoes. Academic Press, London, UK, pp. 263-269.

Reimer, P.J., Baillie, M.G.L., Bard, E., Bayliss, A., Beck, J.W., Blackwell, P.G., Ramsey, C.B., Buck, C.E., Burr, G.S., Edwards, R.L., Friedrich, M., Grootes, P.M., Guilderson, T.P., Hajdas, I., Heaton, T.J., Hogg, A.G., Hughen, K.A., Kaiser, K.F., Kromer, B., McCormac, F.G., Manning, S.W., Reimer, R.W., Richards, D.A., Southon, J.R., Talamo, S., Turney, C.S.M., van der Plicht, J., Weyhenmeyer, C.E., 2009. IntCal09 and Marine09 radiocarbon age calibration curves, 0e50,000 years cal BP. Radiocarbon 51 (4), 1111e1150.

Reynolds, J.H., 1987. Timing and sources of Neogene and Quaternary volcanism in south-central Guatemala. J. Volcanol. Geotherm. Res. 33, 9-22.

Rose, W.I., Conway, F.M., Pullinger, C.R., Deino, A., McIntosh, K., 1999. An improved age framework for late Quaternary silicic eruptions in northern Central America. Bull. Volcanol. 61, 106-120. https://doi.org/10.1007/s004450050266.

Saxby, J., Gottsmann, J., Cashman, K., Gutiérrez, E., 2016. Magma storage in a strike-slip caldera. Nat. Commun. 7, 12295https://doi.org/10.1038/ncomms 12295.

Sheets, P.D., 1979. Environmental and cultural effects of the Ilopango eruption in Central America. Volcan. Act. Hum. Ecol. 525-564, ill. https://doi.org/10.1016/ B978-0-12-639120-6.50022-4.

Sofield, D., 2004. Eruptive history and volcanic hazards of Volcan San Salvador. Geol. Soc. Am. Spec. Pap. 375, 147-158.

Steiger, R.H., Jäger, E., 1977. Subcommission on geochronology: convention on the use of decay constant in geo- and cosmochronology. Earth Planet. Sci. Lett. 36, 359-362.

Sun, S.S., McDonough, W.F., 1989. Chemical and isotopic systematics of oceanic basalts: implications for mantle composition and processes. In: Saunders, A.D., Norry, M.J. (Eds.), Magmatism in the Oceanic Basins. 42, Geological Society of London Special Publication, pp. 313-345.

Suñe-Puchol, I., Aguirre-Díaz, G.J., Dávila-Harris, P., Miggins, D.P., Pedrazzi, D., Costa, A., Ortega-Obregón, C., Lacan, P., Hernández, W., Gutiérrez, E., 2019. The Ilopango caldera complex, El Salvador: origin and early ignimbrite-form- 
ing eruptions of a graben/pull-apart caldera structure. J. Volcanol. Geotherm. Res. 371, 1-19. https://doi.org/10.1016/j.jvolgeores.2018.12.004.

Taylor, J.R., 1977. An Introduction to Error Analysis: The Study of Uncertainties in Physical Measurements, 327 pp., Univ. Sci. In: Books. Mill Valley, Calif.

Weber HS, Wiesemann G, Wittek indt H (1974), Mapa Geológico de la República de El Salvador/Geologische Übersichtskarte der Republik El Salvador 1: 500,000 (after geological maps 1:100000 - 1967-74) Bundesanstalt für Geowissenschaften und Rohstoffe, Hannover; Bundesanstalt für Bodenforschung, Hannover.
Williams, H., Meyer-Abich, H., 1955. Volcanism in the southern part of El Salvador, with particular reference to the collapse basins of Lakes Coatepeque and Ilopango. Geol. Sci. Univ. Calif. Publ. 32, (64 p).

Wohletz, K.H., 1986. Explosive magma-water interactions: Thermodynamics, explosion mechanisms, and field studies. Bull. Volcanol. 48 (5), 245-264.

Wohletz, K.H., Zimanowski, B., Büttner, R., 2013. Magma-water Interactions. Modeling volcanic processes. Cambridge University Press, New York, 230-257.

York, D., 1969. Least squares fitting of a straight line with correlated errors. Earth Planet. Sci. Lett. 5, 320-324. 